Pamiętnik Literacki 2017, 4, s. 133-170

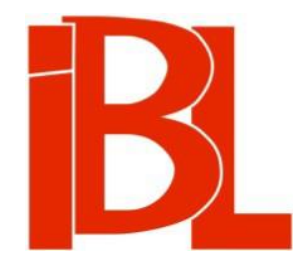

\title{
Maria Dąbrowska - Stanisław Stempowski. Z listów 1924-1939
}

oprac. Ewa Glębicka 
2. $\begin{array}{llllllllllllllllllll} & \mathrm{M} & \mathrm{A} & \mathrm{T} & \mathrm{E} & \mathrm{R} & \mathrm{I} & \mathrm{A} & \mathrm{L} & \mathrm{Y} & \mathrm{I} & \mathrm{N} & \mathrm{O} & \mathrm{T} & \mathrm{A} & \mathrm{T} & \mathrm{K} & \mathrm{I}\end{array}$

Pamiętnik Literacki CVIII, 2017, z. 4, PL ISSN 0031-0514

DOI: $10.18318 / \mathrm{pl} .2017 .4 .9$

\title{
MARIA DĄBROWSKA - STANISŁAW STEMPOWSKI Z LISTÓW 1924-1939*
}

\author{
Opracowała \\ EWA GŁĘBICKA Instytut Badań Literackich PAN, Warszawa
}

Dwugłos korespondencyjny autorki Nocy i dni i jej wieloletniego towarzysza życia trwał 27 lat i zakończył się w r. 1951, krótko przed śmiercią Stanisława Stempowskiego. Pierwsze listy, okazjonalne i grzecznościowe, wysyłali do siebie, nie znając się osobiście, jeszcze za życia Mariana Dąbrowskiego, zmarłego nagle jesienią 1925. Trwająca blisko trzy dekady wymiana listów (których liczba sięga 1052) sytuuje się wśród najbardziej znaczących i najciekawszych zespołów korespondencji. Włącza się w nowy nurt badań nad życiem i twórczością pisarki, zapoczątkowany serią kolejnych wydań jej Dzienników w opracowaniu Tadeusza Drewnowskiego, a następnie edycjami jej korespondencji. Wcześniej opublikowana została korespondencja $\mathrm{z}$ mężem ${ }^{1}$. Następnie ukazała się ważna edycja Maria Dąbrowska, Jerzy Stempowski. Listy 1959-1965². Planowany jest druk kilkutomowego wyboru z ogromnej korespondencji Dąbrowskiej z Anną Kowalską (całość za lata 1940-1964 obejmuje 3170 obszernych listów). Wymienione edycje i prace w przygotowaniu dotycza korespondencji $z$ osobami $z$ jej najbliższego kręgu. W dalszej przyszłości należałoby wydać także listy wymieniane z twórcami krajowymi i emigracyjnymi; $z$ tego obszaru ukazała się jedynie książka Tadeusz Sutkowski - Maria Dabrowska. Listy 1943-1959³.

Listy Marii Dąbrowskiej, podobnie jak jej diariusz, są przede wszystkim cennym świadectwem życia osobistego, zawierają też liczne wypowiedzi i relacje na temat jej własnej twórczości, a także komentarze, odnoszące się do bieżących wydarzeń społecznych, politycznych i kulturalnych. Po opublikowaniu Dziennikó $w^{4}$ korespondencja autorki Nocy i dni jest nie mniej istotnym, przy tym zaś frapującym świadectwem jej życia.

Stanisław Stempowski to postać nieco zapomniana i niesłusznie postrzegana głównie

* Niniejsza publikacja stanowi fragment projektu badawczego finansowanego przez Narodowe Centrum Nauki, zrealizowanego w ramach umowy UMO-2011/01/B/HS2/03285.

$1 \quad$ Ich noce i dnie. Korespondencja Marii i Mariana Dabrowskich 1909-1925. Oprac. E. Głę b i ck a. Warszawa 2005.

2 Maria Dabrowska, Jerzy Stempowski. Listy 1959-1965. Oprac. A. S. Kow a lc zy k. T. 1-3. Warszawa 2010.

3 Tadeusz Sułkowski - Maria Dąbrowska. Listy 1943-1959. Oprac. E. Głę bick a. Skierniewice 2007.

4 Przytaczając cytaty z Dzienników M. D ą b r ow s k i ej korzystałam z pełnego, 13-tomowego wydania (bez opracowania edytorskiego) pod kierunkiem T. Drew n ow s ki e g o: Warszawa 2009. Do pozycji tej odsyłam skrótem Dz. 
w kategoriach towarzysza życia pisarki. Wybitny intelektualista, wolnomularz, znawca problematyki ukraińskiej i cichy doradca ówczesnego MSZ - wprowadził Dąbrowską w środowisko intelektualne, które wywarło przemożny wpływ na ukształtowanie się jej dojrzałego światopoglądu i filozofii życia. W swoich listach przedstawia się czytelnikowi jako człowiek wysokiej kultury osobistej i intelektualnej, ciepły i troskliwy, dowcipny, a jednocześnie jako opiekuńczy duch pisarki, przeżywającej załamanie psychiczne po przedwczesnej śmierci męża. Korespondencja ta potwierdza przypuszczenia, że Stempowski miał, jako pierwszy czytelnik i doradca, znaczący wpływ na ostateczną redakcję Nocy i dni. To on w dużej mierze współtworzył świat lektur Dąbrowskiej, był jej dyskretnym przewodnikiem po wysokiej literaturze i publikacjach dotyczących spraw społecznych.

Przedstawiono tu 19 najbardziej interesujących rękopiśmiennych listów, wybranych z zespołu korespondencji okresu międzywojennego ${ }^{5}$, stanowiących pewne całostki tematyczne, a dotyczących w dużej mierze pracy Dąbrowskiej nad Nocami i dniami, jak też nad innymi utworami. Niektóre jej listy mają sporządzone przez nią maszynopisowe odpisy, różniące się od rękopisów - jest to, jak można przypuszczać, ślad jej intencji, by przygotować je do druku; podobnie redagowała ona korespondencję $z$ mężem, w wielu przypadkach opuszczając spore fragmenty czy modyfikując wiele sformułowań.

W pewnych okresach listy były numerowane - Stempowski robił to bardziej skrupulatnie, Dąbrowska nie zawsze pamiętała wcześniejsze numery lub zaczynała je wstawiać dopiero przy kolejnej przesyłce, często więc na jej listach Stempowski dopisywał numer, jego zdaniem, właściwy, lecz i on niekiedy się mylił. Niektóre swoje listy Stempowski żartobliwie nazywał „raportami”, nadając im kolejne numery; były to zwykle relacje $z$ wykonania przeróżnych zadań, których się podjął, ale także zwyczajne opisy codziennego życia domu. Widoczne tu luki w numeracji wynikają $z$ faktu, że dokonano wyboru kilkunastu listów spośród ponad $650 \mathrm{z}$ lat 1924-1939.

Listy pisane były na papeterii formatu A5, niebieskim lub czarnym atramentem. Większość z nich zachowała się bez kopert.

W publikowanych tu listach, ułożonych w porządku chronologicznym, zmodernizowano pisownię oraz interpunkcję, zachowując jednakże niektóre charakterystyczne cechy, jak np. stosowanie myślnika po kropce - np. w miejscach, gdzie pojawiał się nowy wątek. Ujednolicono wcięcia akapitowe oraz układ nagłówków, dat i podpisów.

Listy przechowywane są w Muzeum Literatury w Warszawie (sygn. 2050, 2071) i w Gabinecie Rękopisów Biblioteki Uniwersyteckiej w Warszawie (sygn. 1389, 1564); w niniejszej publikacji przy ich opisie zastosowano skróty: Muz. Lit. oraz BUW.

\section{Maria Dąbrowska}

[Warszawa,] 19 XII [19]24

\section{Szanowny i Drogi Panie,}

Ani Twego adresu, ani żadnej a żadnej o sobie wiadomości - dla ludzi, którzy chociaż mało może Pana obchodza, ale których Pan za to bardzo obchodzi. Chciałoby [się] wiedzieć, jak się też Szanowny Pan miewa. Trzeba chodzić po świecie i zbierać $\mathrm{z}$ dziesięciu niepewnych stron wiadomości o Pana zdrowiu - i to jest smutne.

Ale za to dobre jest to, że jak słychać, podobno czuje się Pan znacznie lepiej, a może już zupełnie dobrze w tym jakimś Piorunowie ${ }^{1}$. Gdzie to jest ten Piorunów

5 Równie ciekawa jest korespondencja $z$ lat 1940-1951. 
i ten Lutomiersk ${ }^{2}$ - czy to jest gdzie w kaliskich stronach, to by znaczyło w moich stronach.

Bo ja jestem $z$ kaliskiego i Uśmiech dzieciństwa ${ }^{3}$, jeżeli Pan raczy pamiętać taką rzecz - to jest właśnie o Kaliskiem.

Nie wiem, czy Pan tam pozostaje na Święta. W każdym razie przesyłamy Panu opłatek i życzymy Wesołych Świąt i wszystkiego najlepszego, a przede wszystkim zdrowia, a dla nas prędkiego Pana powrotu do Warszawy i obiecanego tak dawno wieczoru u nas z Pana opowieściami. I serdecznie pozdrawiamy prosząc o parę słów bodaj wiadomości.

Najserdeczniejsze, najserdeczniejsze pozdrowienia.

19 XII $24 \mathrm{r}$.

\section{Marian $^{4}$ i Maria Dąbrowska}

List bez koperty; rękopis. Muz. Lit., sygn. 2050, t. 1, k. 1-2.

1 Piorunów - wieś w województwie łódzkim, w powiecie łaskim. Przed drugą wojną światową należała do rodziny Niemyskich. Leon Ni e m y s k i był fabrykantem, ale też wydawcą i współredaktorem socjalistycznego pisma „Ogniwo” (1902-1905); na ten okres datuje się jego przyjaźń ze Stempowskim. W latach dwudziestych XX wieku Piorunów należał do syna Niemyskiego, Lucjana. W latach 1927-1933 pisarka kilkakrotnie tu przyjeżdżała, tu także w 1933 r. pracowała nad tomem 4 Nocy i dni. Imiona właścicieli Piorunowa noszą w powieści Barbara Niechcicowa i Lucjan Kociełł. Na terenie wsi znajdują się liczne stawy hodowlane, w których rosły lilie wodne. Być może, stały się one inspiracją słynnej sceny w powieści. W czasie okupacji niemieckiej Niemyscy zostali usunięci z Piorunowa i przenieśli się do willi „Borowin” w Podkowie Leśnej, gdzie po upadku powstania warszawskiego zatrzymali się na krótko Dąbrowska ze Stempowskim oraz Anna i Jerzy Kowalscy. Lutomiersk - gmina wiejska w województwie łódzkim, nieopodal Piorunowa.

M. D ą b r ow s ka, Uśmiech dzieciństwa. Wspomnienia. Warszawa-Kraków 1923.

Marian Dąbrows ki (1882-1925), mąż Marii Dąbrowskiej, młodszy brat Józefa Dąbrowskiego (Grabca), major Wojska Polskiego, historyk, publicysta, wolnomularz. W roku 1924 pełnił służbę w Oddziale Wyszkolenia Dowództwa Okręgu Korpusu Nr 1 w Warszawie, a następnie był szefem Departamentu Wyznań Niekatolickich w Ministerstwie Spraw Wojskowych. Zmarł na atak serca w Kosowie Huculskim.

\section{Stanisław Stempowski}

Piorunów, p. Lutomiersk, 31 XII 1924

Drodzy Państwo,

Dzięki za pamięć i dobre słowa. I za uśmiech dzieciństwa, który spłynął ku mnie w kruchym opłatku.

Tak, przebywam w kraju, z którego Pani wyczarowuje takie cudeńka. Coś mi o tym jakby już dawno mówiło. A teraz rozglądać się będę po drogach, zali nie spotkam potwornego Nikodema ${ }^{1}$.

Nie odzywałem się do nikogo, gdyż pisać mi było i jest jeszcze ciężko. Niedawno zwlokłem się dopiero z łóżka, siły do cna wytlały. Ubyło 23 funty, prawie ćwiartka cielęciny. Już się jednak coś przesila i wkrótce pewnie wrócę.

Serdeczne pozdrowienia i życzenia noworoczne najlepsze.

St. Stempowski

List bez koperty; rękopis. Muz. Lit., sygn. 2071, t. 1, k. 1. 
1 Mowa o bohaterze opowiadania M. Dą b r ow ski ej Noc ponad światem, napisanego w maju 1924, opublikowanego w „Wiadomościach Literackich” (1924, nr 50, s. 3-4. Przedruk w: Ludzie stamtad. Warszawa 1926, s. 113-140).

\section{Maria Dąbrowska}

Jamno, 4-VII-[19]26

Drugi raport ${ }^{1}$ Kochanego Pana otrzymałam. To, co Pan napisał o przyjemności, jaka mu sprawiła wizyta doktorowej ${ }^{2}$, wystarczyło, ażebym do nich ${ }^{3}$ napisała najserdeczniejszy list. Zasmuciłam się, że w środę znów serce bolało - czy teraz jest już lepiej? I proszę uważać na niemądry przedostatni list ${ }^{4}$ i o każdym usposobieniu ducha pisać, a nie pisać wcale, kiedy pisanie męczy.

Mnie już na długie godziny ogarnia ta furia pracy, która mnie czyni martwą wobec życia zewnętrznego, całkiem wywróconą do środka. Na razie ta praca nie ma jeszcze nic wspólnego z powieścią, ale powieść już nurtuje pod spodem ${ }^{5}$. A jeśli po pracy i ogarną mnie chwilowe lęki, nagłe obrzydzenie do życia i niesmak ze snującymi się myślami w rodzaju: a któż to będzie czytał? Dla kogóż piszę? albo czy to w ogóle co warte, czy to jednak nie sa zdawkowe śmiecie, to jak słodka pociecha przychodzą myśli o tym, co mi jest najczulszą osłodą i podporą, a w snach listy mieszają mi się w niewyrażalny sposób z woniami róż, $\mathrm{z}$ płatkami róż, z jakimiś wędrówkami przez wronie ulice Warszawy - to wzmacniam się na duchu.

Postanowiłam sobie do 15-go napisać wszystkie artykuły i recenzje, które dawniej obmyśliłam, po południu kończę tłumaczyć Jacobsena ${ }^{6}$. Od 15-go będa próby nad powieścią, po południu przygotowywanie Jacobsena do druku. Niekiedy przychodzą srogie wattpliwości, zapytania, po co ja piszę te recenzje, czas, by przestać, prawda Paneczku? - to do niczego niepodobne, prawda, Paneczku? Niech Pan mi poradzi. Ja sama nie rozumiem, co mnie pcha do pisania recenzji, powieściopisarz właściwie nie powinien, ale coś mnie pcha.

Tutaj wczoraj pszczoły uroiły się na poddaszu - przyleciały aż ze wsi i pani Maria ${ }^{7}$ kupiła ten rój. Może to wróżba dla Jamna i dla mnie, co?

Teraz cały dom dźwięczy tak ślicznie jak wiolonczela. I co za zmierzch dziś - co za wieczór - co za pogoda.

Trzym się mocno, Paneczku, bo cóż to będzie za radość, jak się spotkamy, co za opowiadania, jak było dzień po dniu.

Ja też czasem upadam na duchu w mój dawny znany Panu sposób, ale wierzę, że wszystko musi być dobrze, krzepię się wspomnieniami o tym, czym mnie los darzy - i złe chwile mijają.

Ściskam najdroższe ręce i pozdrawiam najsłodszymi słowami

$\mathrm{Ma}-$

List bez koperty; rękopis. Muz. Lit., sygn. 2050, t. 1, k. 13-14. Odpis maszynopisowy: BUW, sygn. 1564, 3-4; pod odpisem numer: (47).

1 Pierwszym „raportem” „(żałośnym)” był list z 27 VI 1926, w którym Stempowski pisał, jak bardzo jest mu smutno po wyjeździe Dąbrowskiej.

2 Mowa o nie znanej z imienia żonie dra Jana Władysława Adamskiego.

3 Chodzi o Jana Władysława A d a m s k i e go (1882-1958), lekarza internistę i higienistę, działacza społecznego, wolnomularza, przyjaciela Stempowskiego. Od roku 1918 był urzędnikiem Minister- 
stwa Zdrowia, następnie zastępcą dyrektora Departamentu Służby Zdrowia Ministerstwa Pracy i Opieki Społecznej, prezesem Polskiego Związku Przeciwgruźliczego, wiceprezesem Polskiego Towarzystwa Medycyny Społecznej, członkiem licznych organizacji lekarskich. Po drugiej wojnie światowej pracował jako adiunkt w Państwowym Zakładzie Higieny.

4 Dąbrowska miała na myśli list z 30 VI 1926, pisany w Jamnie nad Bugiem, gdzie odpoczywała jako gość Marii Markowskiej-Minkiewiczowej, żony gen. Henryka Minkiewicza w ich domu letniskowym. List określała jako „niemądry” być może dlatego, że pozwoliła sobie na sentymentalne wspomnienia i nieco pretensjonalne rozważania o śmierci. Wyznawała m.in.: „We dnie piszę, a kiedy nie piszę i nad wieczorem, to chodzę nad Muchawcem (stać nie można, bo komary). Bywa mi wtedy tęskno w sposób nieugaszony do wszystkich i do wszystkiego - do Matki, do przeszłości, przyszłości i tego, co jest naokoło i z czym się też nie można zespolić - do chłopca, który mi umarł, do jego objęć wspaniałych - i do Ciebie Paneczku, który jesteś, a umykasz się jak powietrze, do rozmów z Panem, do naszej czarownej odnalezionej bliskości, do świecącego uśmiechu i do spojrzenia, które jest przy uśmiechu niebieskie, a kiedy indziej brunatne, jak upalony cukier. [...] Patrzę na wodę, na jej powierzchnię powleczoną odbiciem nieba, niewinnie gładką, leniwą, ledwo że ledwo płynącą. Taka sama bliska jak powietrze, które nas tak bezpiecznie owiewa, jak ziemia, po której tak bezpiecznie stąpamy - a tak łatwo w niej śmierć znaleźć. Jeden krok. Woda. I ogień”.

5 W tym czasie Dąbrowska zaczęła szkicować powieść Domowe progi (pierwsza wersja Nocy i dni). Przypływ energii twórczej przypisywała zbawiennemu wpływowi Stempowskiego. Jednocześnie szkicowała inną powieść, Wieś na pagórkach (ostatecznie nie zrealizowała pomysłu); bohaterką miała być Agnieszka (lub: Natalia) Śniadowska (!), wdowa, która w dwa lata po stracie męża postanawia przenieść się na wieś.

W pierwszej połowie maja 1926 pisarka zrezygnowała ostatecznie z pracy biurowej. Spodziewając się otrzymania obiecanego stypendium od Mortkowicza, zamierzała wyjechać na kilka miesięcy na wieś, by skoncentrować się na pracy nad powieścią, którą w r. 1928 drukowała w „Kobiecie Współczesnej” pt. Domowe progi.

$6 \quad$ J. P. J a c o b s e n, Niels Lyhne. Powieść. T. 1-2. Przekł., wstęp M. D ą b r o w s k a. Warszawa 1927. Jens Peter J a c o b s e n (1847-1885), powieściopisarz i poeta duński, uznawany za jednego z najwybitniejszych twórców skandynawskich, z wykształcenia biolog, propagator idei darwinizmu. Jego autobiograficzną powieść Niels Lyhne (1880) Dąbrowska czytała w przekładzie niemieckim przed 1914 rokiem.

7 Maria Markowska-Minkiewiczowa (1878-1939), pisarka, publicystka, tłumaczka, żona gen. Henryka Minkiewicza.

\section{Stanisław Stempowski}

Raport $4^{1}$

[Warszawa,] 5 lipca [1926], poniedziałek

List polecony otrzymałem w sobotę rano i tegoż dnia poleciłem Serafinowi ${ }^{2}$, gdy zjawił się do koryta, żeby doręczył rękopis Stpiczyńskiemu ${ }^{3}$. Okazało się, że Stp[iczyński] wyjechał z odczytem gdzieś na prowincję, Serafin tedy czyha na jego powrót i sprawę załatwi z nim (lub z Zawist[owskim]) ${ }^{4}$, a o wszystkim sam kartką do Pani napisze.

Wczoraj była pierwsza eskapada w świat. Cały ranek szykowałem się do niej jak sójka za morze. Ramię pobolewa niczym ząb, nogi wciąż miękkie, więc coraz to pokładałem się na ludwiku. Po sjeście obiadowej porwały mnie „śliczne bęcwały” na auto i powiozły na Trzeci Most ${ }^{6}$. Dawno nie doznawany przestwór, słońce, pęd powietrza, niedzielna niefrasobliwa ciżba - odurzyły mnie radośnie, jak tęgie wino. Snującą się spodem leśmianową melancholię - „czemuż nie ma ust moich na łące!”7 - tłumiło wypełniające mnie całego bez reszty poczucie, że właśnie w tym „straconym” czasie spłynęła na mnie nieoczekiwana już łaska szczęśliwości, z którą mógł- 
bym istnieć poza czasem, nawet w skorupce orzecha. Toteż w powrotnej drodze z wysokości mostu spoglądałem $\mathrm{z}$ politowaniem na kiszące [się], niby zlot pingwinów lub tarło sardynek, mrowie ciał na brzegu i w wodzie.

Kochanych listów Pani otrzymałem trzy ${ }^{8}$ (nie licząc poleconego). Są one niewyczerpanym, chociaż wciąż czerpię, źródłem radości i osnową mojego życia. Czas liczę od listu do listu, a błogosławiąc dobrą rączynę niezmordowanie (acz krzywo) pisząca, życzę owemu sadzami posypanemu Szymszelowi ${ }^{9}$ zdrowia i częstych podróży do B[rześcia] n/ B[ugiem].

Jak już pisałem, ze zdrowiem coraz lepiej; dziś byli obaj lekarze, Ad[amski] i Stef[anowski ${ }^{10}$, i przepisawszy wszelakie ostrożności i leki, pozwolili w końcu tygodnia jechać na urlop. Wyjadę pewnie w piątek lub w sobotę wieczorem na Wołyń. Jutro będę $z$ wizytą u Adamskich. Coraz więcej mam co dzień odwiedzających, którzy mnie nużą i czas odbierają. Dziś np. przyniosło Fr[anciszka] Potockiego (z „Czasu”) ${ }^{11}$, który zwykle raz w roku bywa, żeby nawrócić mnie na katolicyzm. Ale zdarzył się i miły gość ${ }^{12}$, za którego przyczyną będę mógł z Najmilszą Panią na jesieni chodzić do teatrów. Wrócił z Paryża, gdzie przebył b[ardzo] ciężką operację, i ten dzień przed operacją, gdy musiał zastanowić się nad skończonym życiem i rozdysponować rzeczy i sprawy swoje, wyniósł go na jakieś szczyty pogody i mądrości - oczy mu poweselały i fałdy koło ust wygładziły się. Winszowałem mu i powitałem bratnią duszę, na tej wyniosłości bowiem już byłem, i to nie raz.

Wtorek, wieczór

Nadszedł rano list czwarty ${ }^{13}$. Rumiany listek nawet nie przysiadł, tamte jednak motyle $z$ świętymi hieroglifami były łaskawsze. Choć oczywista krzywda moja z tego wyniknie, z szacunkiem i pokora odczytałem o „furii pracy”. Tak, tak. Odwalić jak najprędzej przekłady i recenzje, wśród których upadają śmieszne wątpliwości, a zanurzyć się w te właśnie podspodnie nurty swoje i wynosić stamtąd cudne skarby na świat, nie zatajać jak skapiec i nie marnować - jak nie powiem kto. Nie ginie się dla kogoś czy czegoś - czas przychodzi i nie ma rady. Trzeba wydać na świat. Tylko się skupić w sobie i wsłuchać w to, co już pogrywa.

Moja przecie krzywda, a ręce składam modlitewnie, bo wierzę. $Z$ tym przypadam do rąk i bez liku całuję

List bez koperty; rękopis. BUW, sygn. 1389, k. 3-4.

1 Wcześniejszy „Raport nr 3” to list z 1 VII 1926, w którym Stempowski pisał o radości z powodu otrzymania listu Marii oraz relacjonował stan swojego zdrowia, a także wizyty przyjaciół. List zaczął od inwokacji: „Same dobre wiadomości! Tak jakoś składnie poszło od samego rana. Na dzień dobry powitał mnie list ( $\mathrm{Nr} 2$ ). Aż oczy zmrużyłem ze szczęścia. Ust moich dotknął złocisty, niby skrzydło motyla, płatek nieznanego mi kwiatu, który wczoraj jeszcze rósł nad leniwą wodą Muchawca. I wnet znalazłem się w niesamowitym świecie, który wchłonął i zawarł mnie w sobie. Słodko i swojo mi w nim, bo to świat Twój, Pani najmilsza, $z$ Ciebie poczęty, przez Ciebie z nicości cudownym darem Twoim dźwignięty, łaską czaru mnie odsłoniony i odtąd mój w Tobie na zawsze. Olśniony i szczęśliwy przebywam w nim [...]".

2 Serafin - pseudonim Jerzego S te m p o w s k i e go (1893-1969), syna Stanisława, używany przez niego w „Drodze” i w „Głosie Prawdy”. Zastępował on w redakcji „Głosu Prawdy” Wojciecha Stpi- 
czyńskiego w czasie jego nieobecności, związanej z działalnością poselską. Dąbrowska współpracowała z „Głosem Prawdy”; w r. 1926 opublikowała tu sześć recenzji.

3 Wojciech St pi c zyń s ki (1896-1936), polityk i publicysta, poseł na Sejm. Należał do radykalnego skrzydła piłsudczyków, w latach 1922-1929 redagował „Głos Prawdy”, następnie „Strzelca” i „Pracę Strzelecka”. W czasie przewrotu majowego prowadził biuro prasowe Józefa Piłsudskiego; był autorem określenia „sanacja”.

4 Władysław Zawistowski (1897-1944), teatrolog, krytyk teatralny, współpracownik Leona Schillera. W latach 1924-1926 redagował „Scenę Polską, a w „Tygodniku Ilustrowanym” i w „Kurierze Polskim" publikował artykuły o teatrze. Być może, za pośrednictwem Zawistowskiego ogłosiła Dąbrowska w „Tygodniku Ilustrowanym” szkic Gtębiej niż dno. O „Opowieściach niepokojacych” J. Conrada (1926, nr 34, s. 556).

5 Nie ma pewności, kogo Stempowski miał na myśli; być może Jerzego Stempowskiego oraz Karola Szteinboka, który często wychodził ze Stanisławem Stempowskim na spacery, gdy ten niedomagał na serce.

6 Trzeci Most - most Poniatowskiego, zbudowany w latach 1904-1914, został wysadzony w powietrze w 1915 r. przez wycofujące się z Warszawy wojska rosyjskie, odbudowany w latach 1921-1926. Fragment wiersza B. Le ś mi a n a Ballada bezludna, z tomu Łaka (Warszawa 1920). Mowa o listach Dąbrowskiej wysłanych z Jamna 30 VI 1926, 1 VII 1926 i 4 VII 1926.

9 Szymszel M ej e r - w 1926 r. Dąbrowska pisała z Jamna do matki, Ludomiry Szumskiej: „Pocztę wozi Żyd wiejski Szymszel, który co dzień prawie jeździ do Brześcia”. Postać Szymszela pojawia się w Nocach i dniach. Tłumaczowi powieści wyjaśniała: „Mejer było nazwisko Szymszela, Szymszel - imię" (M. Dąbrow s ka, list do H. Koitza, nie datowany, sprzed 1938. BUW, sygn. 1380, k. 283). W innym miejscu M. D ą b r ow s k a (To, co pamiętam. Na stronie: Forum Żydów Polskich. http://www.fzp.net.pl/ 〈data dostępu: 15 XI 2017〉) dodawała: „[...] Szymszel jest kombinacja artystyczną dwu postaci: Abrama Fuhsa, wędrownego kramarza, którego pamiętam z lat dziecinnych, i Szymszela, woźnicy z Brześcia nad Bugiem, poznanego przeze mnie już w innych czasach". Antoni S tefa now s ki (1885-1940), lekarz internista, społecznik. Leczył Stefana Żeromskiego pod koniec jego życia oraz wchodził w skład konsylium lekarskiego przed śmiercią Józefa Piłsudskiego. Zginął w kwietniu 1940 w Katyniu. W Dziennikach pod datą 28 VII 1937 D ą b row s ka pisała o nim: „Pacjenci Stefanowskiego zawsze umierają, gdyż on boi się stosować radykalniejszych środków. On był przy Piłsudskim i przy Żeromskim. A Ujejskiego leczył... winem” (Dz. t. 4, s. 41).

11 Franciszek Salezy P ot o cki (1877-1949), właściciel dóbr ziemskich koło Winnicy na Ukrainie, dziennikarz, związany z pismem „Czas”, polityk konserwatywny, w latach 1928-1938 dyrektor Departamentu Wyznań w Ministerstwie Wyznań Religijnych i Oświecenia Publicznego, działacz społeczny. Być może, spotykał się ze Stempowskim z powodu swoich zainteresowań masonerią.

12 Nie udało się ustalić, o kogo chodzi, najpewniej o osobę związaną z Teatrem Polskim w Warszawie (na premiery w nim Stempowski i Dąbrowska do 1939 r. stale otrzymywali zaproszenia).

13 Mowa o liście Dąbrowskiej z 4 VII 1926, w którym opisywała swój pobyt w Jamnie i plany wakacyjnych prac twórczych: przekład z Jacobsena, recenzje dla „Bluszczu”, „Głosu Prawdy” i „Wiadomości Literackich" oraz szkic powieści, jeszcze wówczas bez tytułu.

\section{Maria Dąbrowska}

3) ${ }^{1}$

Krzywda, 11 VIII [19]28 r.

Najdroższy mój,

Bardzo trudno jest dotrzymać słowa, że się będzie do Ciebie $^{2}$ pisało raz na tydzień. Co dzień chce się z Tobą rozmawiać, a choć co parę dni list wysłać. Nic się nie bój, nie martw, że serce bije, serdeńko moje ukochane - uspokoi się znowu pomału, może spróbuj znów jednego $\mathrm{z}$ tych dawnych środków w rodzaju jemioły, a nade 
wszystko leżenie i spokój. A widzisz, złoty, kropelki się przydały. Ja też swoje czasem tu biorę, ale na ogół czuję się bardzo dobrze i dosyć mocno pracuję. Do Fiłosofowa już pisałam... ${ }^{3}$

Wczoraj i dziś napisane rozdziały XX i XXI, oba jeszcze w brulionie, ale już postawione. Niechcicowie kupili place w Oczkowie. - Nie wiem, do czego doprowadzi moja metoda przedstawiania toku zdarzeń za pomoca bezpośredniej akcji i dialogu. To jest metoda uważana za zdobycz nowoczesnej techniki pisarskiej, ale ja posługuję się nią przez niedołęstwo, bo nie umiem opowiadać o negatywach. Wydłuża to niezmiernie wszystko. - Jestem jednakże dobrej myśli.

Zapomniałam Ciebie zapytać, jak ma być ze „Swoboda” - czy będzie ona nadal przychodzić na Polną ${ }^{4}$, czy kazać ją przesyłać do Władzi ${ }^{5}$, a stamtąd Wam odsyłać, napisz, jak zrobić. - Dziś cały tu dom jest pod wrażeniem choroby tego małego chłopca, o którym wspominałam w poprzednim liście ${ }^{6}$. Najadł się mizerii, grochu i miodu, i bardzo szybko zaniemógł, od wczoraj ma wielka gorączkę, był doktor, nie moga go niczym przeczyścić, jest obawa o ślepa kiszkę, o zapalenie kiszek w ogóle - jednym słowem: rwetes. Mały jest bardzo żałosny i biednieńki. Ten list jest trze$\mathrm{ci}^{7} \mathrm{z}$ rzędu. Jeden wysłałam jeszcze $\mathrm{z}$ Warszawy, a drugi tu sama w czwartek zaniosłam na pocztę. Całuję i ja Twoje najdroższe ręce, nigdy nie potrafię Tobie powiedzieć, jak Ciebie kocham ${ }^{8}$.

Twoja Ma.

List bez koperty; rękopis. BUW, sygn.1564, k. 13. Odpis maszynopisowy: BUW, sygn. 1565, s. 26.

1 Numer przekreślony ołówkiem, zapewne ręką Stempowskiego. Poprzednie listy Dąbrowskiej nie były numerowane.

2 Przejście na „ty” w korespondencji Dąbrowskiej i Stempowskiego nastapiło w 1926 r. i dotyczyło jedynie listów; pisząc karty pocztowe, używali form „Pan”, „Pani”, unikając publicznego demonstrowania bliskiej zażyłości.

3 Dmitrij Fił o s o f ow (1872-1940), rosyjski krytyk i eseista, filozof, redaktor. W roku 1919 wyemigrował do Polski, gdzie został współpracownikiem Borysa W. Sawinkowa, w 1921 r. zamieszkał w Warszawie. Redagował czasopisma emigracji rosyjskiej „Miecz”, „Swoboda” i „Za swobodu!” Korespondencja Stempowskiego i Dąbrowskiej z Fiłosofowem wraz z odpisami znajduje się w Gabinecie Rękopisów BUW (sygn. 1561) i w Muzeum Literatury (sygn. 2054; tu także odpisy ręką Stempowskiego, sygn. 2051). Zob. też I. O błą kow s k a - G a la n c i a k, Dymitr Fiłosofow i Maria Dabrowska. Z historii polsko-rosyjskich kontaktów kulturalnych w Dwudziestoleciu międzywojennym. „Acta Polono-Ruthenica” 1999.

$4 \quad$ W październiku 1927 Stempowski przeniósł się na stałe do mieszkania Dąbrowskiej przy ul. Polnej 40. To na ten adres przychodziły czasopisma emigracji rosyjskiej, redagowane przez Fiłosofowa; sporadycznie odbierano je z redakcji, posyłając tam gosposię Dąbrowskiej.

5 Władzia - Władysława Królik owa, z domu Śleszyń ska, gosposia Dąbrowskiej.

6 Tj. w liście z 9 VIII 1928, tu nie publikowanym. Mowa o Stasiu Zagórskim, zwanym w rodzinie Bamą, synku nie znanej z imienia kuzynki właściciela Krzywdy, Władysława Mieczysława Szulc-Holnickiego.

7 Dąbrowska 8 VIII 1928, „na samym wyjezdnym do Krzywdy”, pisała do Stempowskiego (który dwa dni wcześniej udał się na letni odpoczynek do syna), ,prosząc na wszystko o leżenie i zachowanie spokoju przez cały czas pobytu w Zarzeczu" (miała bowiem w pamięci jego niedawne kłopoty z sercem). Wieczorem tego samego dnia wysłała $z$ Krzywdy dłuższy list (datowany: 8 VIII 1928), w którym relacjonowała jeszcze domowe sprawy Polnej i wizyty gości. Kolejny list, datowany: 9 VIII 1928, dotyczył już pobytu w majątku Holnickich, żartobliwie nazwanym przez pisarkę Nawłocią. Ten list byłby zatem czwarty z rzędu, a nie trzeci (Dąbrowska często myliła się w numeracji).

8 Akapit zaczynający się od słowa „Zapomniałam...” pominięty w odpisie maszynopisowym listu. 


\section{Stanisław Stempowski}

$\mathrm{N} 2^{1}$ (nie licząc dwóch kartek)

Zarzecze, 13 VIII [19]28

Po dwudniowym leżeniu w łóżku pozbyłem się kataru i jestem zdrów jak - czy ja wiem, bo i ryby teraz jakieś niepewne. Melduje o tym posłusznie, po czym przystępuję do rzeczy ważniejszych.

A więc list (2) $)^{2}$ otrzymałem, za obraz Nawłoci b[ardzo] dziękuję $e^{3}$. Cieszę się, że właśnie elementy nowości i niegdydziejszości nawłockiej będą tą ożywiająca podnietą, z której plon zbierać będziemy radośnie wszyscy na liliowych kartkach Twoich rękopisów. Ja przede wszystkim. Niczego więcej nie pragnę - prócz tylko jeszcze czegoś, co jest prawie niczym.

Już jestem tu tydzień. Nie powiem, żeby mi się wiodło i z pogodą, i z „samopoczuciem”. Dopiero od wczoraj wybrało się na iście żniwną pogodę - ranki zamyślone, wieczory o cichych, długo niegasnących zorzach, noce $z$ niebem wysokim i wzniosłym. Wczoraj niespodzianie spadł dryndą żydowską Jurek - podziwiam go na tle rodzinnym. B[ardzo] zabawny, niedopasowany i żałosny. Ma tu posiedzieć $\mathrm{z}$ dziesięć dni.

Przeczytałem tu, leżąc według rozkazu, grubą księgę Ulanowskiego p[od] tyt[ułem] Doktor Filut ${ }^{4}$. Jest to chamska apoteoza Dziadka, pełna staropanieńskich kiksów i małpich wykrzywiań się, a jednocześnie obrzydliwy paszkwil na PPS i jego działaczy. Poznałem Daszyńskiego i Pończa ${ }^{5}$. Ostatni zwłaszcza, pod nazwą Faksymilian Polonez, jest potraktowany ze szczególną zjadliwością ${ }^{6}$. Jurek ma o tej książce mieć odczyt ${ }^{7}$. Czytam Moranda ${ }^{8}$ o murzyńskim szaleństwie - są tu ciekawe i trafne spostrzeżenia o człowieku i zwłaszcza kobiecie powojennej.

Gazet nie czytam, do nikogo nie piszę. Dla Ciebie założyłem, według opowiadań Huby $^{9}$, książeczkę pt. Tako rzecze Szmul Tojer. Mam już zanotowanych kilka przypowieści i aforyzmów. Np.:

„Ja swoje pieniądze tak rozrzucam, jak zając swoje dzieci: jedno przepadnie, to drugie się uchowa”.

"Ja procent, a brunboże lichwy nie lubię: andel to jest smaczno”.

„Chłopiec jak pusty, to będzie porządny człowiek; dziewczyna jak cicha - to do niej należy; a chłop jak nie złodziej, to leniwy".

„Ja w tym polowaniu nie widzę nic dobrego: cały dzień chodzić kota szukać! Czemu żaden żydek na polowania nie chodzi?”

„Matka chowa dziecko i myśli, że to będzie ksiądz, a to będzie rozbójnik”.

„Ta krowa ma mleko, ale tylko dla siebie”.

Itd. Nie wiem, może Ci się przyda, to będę notował. Mam i większe przypowieści w stylu biblijnym. (Cóż, czytam Biblię. Przeczytaj: Dzieje Józefa, Hioba, Eklezjastę, Izajasza - to, co ze Starego Testamentu weszło na zawsze w człowieka.)

Kończę, gdyż Hub wyjeżdża na jarmark i piszę naprędce. Jak znajdę odpowiednie słowa, których mi zawsze brak jako niepiśmiennemu, to $\mathrm{Ci}$ napiszę, co jest w miłości najistotniejsze - w świadomości mężczyzny, co staje się, gdy zaistnieje, znakiem największej jego tkliwości i zarazem najsroższego okrucieństwa. Olśniło mnie, gdy czytałem Moranda. 
Poza tym tłumaczę i jem, opycham się czereśniami, które są soczyste jak wino i pachnące jak las w skwarze letnim.

Całuję Twoje najmilsze rączki i najpracowitsze paluszki

St.

List bez koperty; rękopis. BUW, sygn. 1389, k. 5-6.

$1 \quad$ Stempowski pomylił się lub list zaginął; zachowały się jedynie trzy wysłane przez niego karty pocztowe, datowane: 7 VIII 1928, 8 VIII 1928, 11 VIII 1928.

2 Mowa o nienumerowanym liście Dąbrowskiej z 9 VIII 1928. Zob. przypis 3.

3 Nawłocią nazwała Dąbrowska majątek Krzywda, należący do Władysława Mieczysława Sz u lc - Ho ln i c k i e go (1845-1949) i jego pierwszej żony, Janiny Leokadii z Ko w n a c k i c h (1885-1946), w którym autorka Ludzi stamtąd odpoczywała w sierpniu 1928. W jej liście z 9 VIII 1928 (Muz. Lit., sygn. 2050, t. 1, k. 106) czytamy: „Jest nieco uboższa od Nawłoci opisanej przez Żeromskiego, ale jedzenie jest w całości na poziomie Nawłoci. [...] Dom jest na zewnątrz ładny, znasz go zresztą z fotografii, tylko że całkiem nagi stoi na wierzchu ziemi jak pudełeczko, bo nowy i jeszcze niczym nieobrośnięty. W środku zbieranina przypadkowych sprzętów, bez gustu i charakteru, układ pokojów i kształt ich nie zawsze szczęśliwy i estetyczny, dwa tylko pokoje widziałam bardzo piękne. Wszystko razem stanowi całość, do której człowiek się z łatwością przyzwyczaja, przykleja”.

4 Tadeusz Ula now s ki (ok. 1872 - 1942), powieściopisarz, satyryk, publicysta, w latach 1937-1938 redaktor pisma „Ruch Pracowniczy”. Rozgłos przyniosła mu powieściowa satyryczna trylogia polityczna z kluczem personalnym: Doktor Filut (1928), Uczta dozorców (1929) i Ordynans Córuś (1930), atakująca partie i stronnictwa z pozycji demokratycznego skrzydła obozu piłsudczykowskiego.

5 Tak Stempowski i jego przyjaciele nazywali Stanisława P o s n e r a (1868-1930), działacza socjalistycznego, senatora, prawnika i publicystę. Dąbrowska zapisywała ten przydomek bez zmiękczenia: Poncz.

6 Jak pisze badaczka problematyki powieści politycznej, D. D o b row ols k a (Powieść polityczna Dwudziestolecia międzywojennego. Kielce 2000, s. 162): „Trudno dziś dokładnie ustalić, kogo pod tym nazwiskiem pisarz chciał [w powieści Doktor Filut] ośmieszyć. Po zbadaniu kilku biografii posłów socjalistycznych nasuwa się przypuszczenie, że Ulanowski posłużył się metodą Kadena i skleił tę postać z dwóch osób, tj. z przewodniczącego klubu socjalistów w Senacie, posła Norberta Barlickiego, i posła Liebermana. Byli to znani politycy i publicyści, zabierajacy często głos w sejmie i prasie. Postać Poloneza ma jednak z nimi tyle wspólnego, co przysłowiowa już "kukułka z fotografią", jak określił Wyka podobieństwo Bogdy do Witosa”.

7 J. St e m p ow s ki nie cenił twórczości Ulanowskiego - w jego Małym felietonie o niewielkiej ksiażeczce (w: Szkice literackie. T. 1: Chimera jako zwierzę pociagowe. Warszawa 2001, s. 140) czytamy: „Z inspiracji "sanacyjnej" wyszło dotychczas na świat dwóch pisarzy, których dzieła będą zapewne kiedyś latarnią przewodnią po wnętrzach tego obozu. Jest to Juliusz Kaden-Bandrowski i Tadeusz Ulanowski. Mniej więcej równi talentem, obaj próbowali niefortunnie stylu "męskiego", jeden płynąc $\mathrm{w}$ tradycjach legionowych, drugi w ideologii Bebeesu. Obaj od strony wewnętrznej przedstawiaja ten sam obraz histerycznego, inteligenckiego topienia się i załamania w sobie, będacego czkawką po Próchnie Berenta i niektórych stronach Żeromskiego”. S. Stempowski spotykał pisarza w Jaworzu i był przez niego admirowany.

8 Paul Morand (1888-1976), pisarz i dyplomata, członek Akademii Francuskiej, autor powieści, opowiadań i esejów, uznany za kronikarza okresu po pierwszej wojnie światowej. W języku polskim ukazały się powieści Swawolna Europa (1927), Lewis i Irena (1924), Żyjacy Budda (1929) i New York (1930).

$9 \quad$ Huba (Hub) - Hubert Stem powski (1897-1962), młodszy syn Stanisława, z wykształcenia agronom. W latach 1919-1920 uczestniczył w walkach polsko-ukraińskich i polsko-bolszewickich. Dzierżawił majątek ziemski w Zarzeczu, w powiecie chełmskim, w latach trzydziestych był starosta włodzimierskim i prezydentem Łucka. Po wojnie pracował w Państwowych Gospodarstwach Rolnych. W roku 1948 był więziony z powodów politycznych. 


\section{Maria Dąbrowska}

4)

Krzywda, 15 VIII [19]28

Najmilszy.

Dzięki za drugi list ${ }^{1}$, otrzymuję tu Twoje listy nazajutrz. U mnie wszystko w dalszym ciagu dobrze. Dwudziesty rozdział powieści, jak i poprzedni, rozpadł się na trzy, wszystkie trzy już napisane w brulionie, a XX też dziś przepisany na czysto. Rozdziały są dobre, żywe i barwne, ale wszystko, co się ma dziać, dzieje się zabójczo powoli, nie mogę na to poradzić - nie wiem, co z tego będzie, ale jestem dobrej, spokojnej myśli. W każdym razie myślę, że za tydzień skończę pierwszą część i zaraz zacznę szkicować drugą, w której jednak będzie nie tylko młodość Agnieszki, ale wszystkich trojga dzieci i w ogóle $z$ kłopotów i spraw gospodarza finansowych Niechcicowie mają tu wkroczyć w sferę ziemiańskości - i rzeczy szalonych.

Dostałam tu nowe zamówienie od Ossolineum na cztery opowiadania ${ }^{2}$. Jeśli się na nie zdecyduję, przyniesie mi to $z$ jakie tysiąc pięćset złotych, więc nie zginiemy. Może się zdecyduję, o ile do zimy druga część powieści będzie zaawansowana - wtedy na miesiąc odłożę i dla „płodozmianu” popiszę trochę rzeczy ubocznych.

Przeczytałam na koniec Biesy3. Jest to rzeczywiście paszkwil, a nawet cała intryga, sklecona w sposób sztuczny i mało przekonywający. Ale lwi pazur psychologa, dotknięcie prawie że chirurgicznie precyzyjne obnaża takie żałosne i straszliwe głębie ludzkiej duszy, że aż dreszcz chwilami przechodzi. Dziedziną Dostojewskiego jest ta straszna dziura w duszy, przez którą jeżeli człowiek stapi nieostrożnie, to leci w jakąś otchłań męki bez dna. W każdym człowieku jest takie miejsce, jest ono i we mnie. Jakby wszędzie była podłoga, a w jednym miejscu deska to niby taka sama, ale $\mathrm{z}$ czegoś miękkiego, z papier maché - stapnie i załamie się, trzeba ją ostrożnie obchodzić, bo tam pod spodem hula kosmiczny strach, szaleństwo, negacja wartości życia, zdziczenie, obłęd. We mnie i w nas, ludziach Zachodu surowe poczucie godności, harmonii, ładu i, bo ja wiem, jeszcze czegoś nienazwanego (może „mazurskości”) chroni nas przed wpadnięciem. Przeczytanie Biesów uczyniło mi już całkowicie zrozumiałą całą historię z Jurkiem. A i Fiłosofow nieraz takim stylem mówi, jak u Dostojewskiego, chociaż tak nie męczy. À propos, miałam dziś list długi od Fiłos[ofowa], którego, jak zwykle, nie mogę dobrze odczytać. Odczytasz mi, jak będziemy w Warszawie. Na osobnej karteczce spisuję zdania, które mnie w Biesach uderzyły trafnością czasem rewelacyjną*.

Jestem bardzo ciekawa tego Moranda - będę chciała go przeczytać. I bardzo czekam na to inne, co mi obiecałeś napisać o istocie miłości mężczyzny. Czekam na to aż czegoś z lękiem, powiało na mnie niepokojem radośnie-lękliwym od tych słów.

Co mówi Szmul, wszystko zapisuj, jakże Ci będę wdzięczna, nawet, jeżeli możesz, to mi tu prześlij, bo właśnie ciagle sobie z Żydami nie mogę dać rady.

Co do p. Porazińskiej ${ }^{4}$, o której pisałam w poprzednim liście ${ }^{5}$, to moje przelotne usiłowanie zobaczenia jej sympatyczna, zawiodło. Jest to osoba gderliwa, skrzekliwa, nudna, sentymentalna i pełna niedowarzonych pensjonarskich ambicji w rodzaju powożenia czwórką koni itd., właściwych osobom, które nie wyżyły swej energii we właściwym kierunku. 
Z zazdrością czytam Twoje opisy czereśni, tutaj owoców nie ma na lekarstwo, raz tylko jadłam trochę malin. Zapomniałam jeszcze napisać, że zabrałam cymbałki i Kolberga $z$ pieśniami, może się wprawię i gdy nadejdą $\mathrm{w}$ Warszawie długie wieczory, będę sobie i Tobie brząkała. Całuję, bo kartka się kończy, mogłabym tak pisać bez końca.

Twoja Ma.

* Kartki nie załączam, bo jadę na pocztę.

List bez koperty; rękopis. BUW, sygn. 1564, k. 15. Odpisy maszynopisowe: BUW, sygn. 1565, s. 27; Muz. Lit., sygn. 2051, k. 38-39.

1 Mowa o liście Stempowskiego z 13 VIII 1928, wysłanym z Zarzecza.

2 Dąbrowska kilkakrotnie pisała opowiadania do podręczników szkolnych na zamówienie lwowskiego Ossolineum. Tym razem jednak propozycji nie zrealizowała w całości; w 1929 r. wysłała do Ossolineum opowiadanie $W$ szpitalu, przeznaczone do czytanek dla III klasy szkół średnich w układzie Balickiego i Maykowskiego, w 1930 r. w podręczniku Miej serce ukazało się jej opowiadanie Wyścig pracy (pierwodruk: „Kobieta Współczesna” 1929, nry 23-24).

3 W roku 1928 w Bibliotece Powieściowej „Roju” ukazały się Biesy F. D o s t oj e w s k i e go w przekładzie T. Za górskiego.

$4 \quad$ W Krzywdzie przebywały w tym czasie Janina P o r a z i ń s k a (1882-1971), autorka literatury dla dzieci, i jej matka, Helena z Saryus z-Bielskich.

5 W nie publikowanym tu liście z 12 VIII 1928 Dąbrowska pisała: „W tej chwili p. Porazińska pobiegła słuchać mowy biskupa Bandurskiego. [...] Zapomniałam poprzednio dodać, że jest tu i panna Porazińska. $Z$ początku robiła na mnie wrażenie niemiłe bardzo stetryczałej starej panny - teraz jednak wrażenie bardzo się poprawiło. Jest shisteryzowana, ale poczciwa, inteligentna. Wczoraj rozmawiałam z nią długo, bo chodziłyśmy razem na spacer. Jest ona redaktorka jakichś wypisów, które wydaje firma Jakubowskiego we Lwowie. Płaca jej tam tak dobrze, że kupiła sobie ziemię w Wiśle, a teraz nauczyła się szoferki i chce kupić samochód".

\section{Maria Dąbrowska}

Krzywda, 20 VIII [19]28

Ostatni rozdział pierwszej części już w brulionie napisany. Cóż, kiedy znowu rozpadł się na trzy, ale tym razem już nieodwołalnie koniec. A może, jak wszystkie części gotowe będą, to zacznę stosować skróty. Tymczasem narasta to jakoś jak lawina. A najstraszniejsze, że ja wciąż nie wiem, czy i co ja mam do powiedzenia. Piszę już teraz jakby żmudną kronikę, dyktowaną przez kogoś. Ale metoda „zamknięcia się w klasztorze" okazała się dobra - cały prawie dzień mam wypełniony pracą, od której nic mnie ani przykrego, ani przyjemnego nie odrywa. Naokoło szarość pogody i krajobrazu, a tu wewnątrz iskrzy się od rozmaitych wzruszeń, które przeżywam. Ale długo w tym reżimie nie wytrzymam i już liczę dnie do powrotu, a teraz to już nawet i zgiełk Warszawy przedstawia mi się w ponętnych barwach.

Przypatruję się tu różnym ludziom, którzy się przewijają. W święto i w niedzielę przyjeżdżają zawsze goście. Rozmowy są dla mnie pouczające, o i mocno. Później w Warszawie na naszych popołudniowych sjestach na ludwiku wszystko Ci poopowiadam. Byli tu pp. Stefanowie Dmochowscy z Sienkiewiczowskiego Burzca ${ }^{1}$. On jest przyjacielem Wacka ${ }^{2}$, napisał z nim jaką́s książkę o spirytusie ${ }^{3}$ - oprócz tego znają panią Sobańską, która nawet bawiła tu w Burzcu niedawno, minęłyśmy się 
w drodze ${ }^{4}$ Zaprosili mnie do Burzca, gdzie mam oglądać lipę, pod którą pan Zagłoba siadywał z Jaremką i Longinkiem. W zeszły czwartek jeździłam tu zwiedzić hutę Dąbrowę ${ }^{5}$, która znajduje się w pobliżu. Zrobiła na mnie piorunujące wrażenie. Wyobraź sobie hute położoną w upiornym krajobrazie nagich wydm i nieużytków, z gromadą ohydnych żydowskich domostw naokoło, a dalej po polach rozrzucone domki hutników. Huta daje swoim robotnikom po trochu ziemi, nie ziemi raczej, a rozpaczliwego nieużytku. Na tych nieużytkach robotnicy budują sobie nie domki, a chlewy, psie budy, szałasy czy też klitki, co chcesz, naokoło, na nędznym ściernisku, gdzie między źdźbłami wozem by można zawrócić, wiatr podnosi tumany kurzu. Widok robotników przy piecach, jak zataczają po powietrzu metalową rurą z czerwoną kulą roztopionego szkła na końcu, jakby się złowrogo bawili w niesamowite ogniste piłki, wstrząsnął mną tak, że - wstyd powiedzieć - łzy mi pociekły. Kiedy patrzyłam na to, nie dziwiłam się już niczemu, wszystkie straszne rzeczy, które się dzieją na świecie, są w takim oświetleniu możliwe i usprawiedliwione. Coś nęciło, żeby tak zostać tam i doznać tego losu. Śród dymu, ognia i kurzu na rozłogu fabrycznym, niby urocza pociecha, stoją dwie olbrzymie, jak nigdy nie widziałam, okryte koralowymi jagodami, prześliczne jarzębiny.

Wczoraj przyjechał tu z Rabki z gospodynią, panną Eweliną ${ }^{6}$ - syn pp. Holnic$\mathrm{kich}^{7}$, Jaś. Owa p. Ewelina, gdzieś tam od Was, dzieci nazywaja ją „ciotką” - brzydulka, otyła i purpurowa, typowy obraz istoty przywiązującej się do cudzego ogniska i żyjącej dla niego ze wszystkich sił. Jaś jest w istocie pełnym uroku chłopcem, cichym i nieśmiałym. W tej parze Dzidzia jest chłopcem, a on dziewczynka. Ale, niestety, robi wrażenie trochę niesamowite i nienormalne. Jest chory nerwowo, ma ostry tik nerwowy i silne zaburzenia mowy. Mówi tak, jakby ledwo że ledwo sylabizował. Jest jednak bóstwem tego domu.

$Z$ początku były częste od Ciebie wiadomości, ale teraz już od czterech dni nie ma i tęskno. Całuję bardzo drogiego, miłego ${ }^{8}$

Twoja Ma.

List bez koperty; rękopis. BUW, sygn. 1564, k. 16. Odpisy maszynopisowe: BUW, sygn. 1565, s. 28-29; Muz. Lit. sygn. 2051, k. 39-40.

1 Stefan D moch ow ski (1874-1959) spowinowacony był z Henrykiem Sienkiewiczem (w XIX w. Burzec stanowił własność wuja autora Trylogii, Aleksandra Dmochowskiego).

Jadwiga D mochowska, z domu Waydel (1893-1962), córka znanego, postępowego adwokata i działacza społecznego, Emila Waydla i Wandy z Lubińskich, 2 voto Pankiewiczowej, tłumaczka, autorka wspomnien.

2 Wacław Dąbrowski (1879-1962), szwagier Dąbrowskiej, starszy brat Mariana, mikrobiolog, profesor i rektor SGGW, założyciel i redaktor czasopism „Przemysł Gorzelniany” oraz „Przemysł Rolny".

3 S. D mo chow ski, W. Dąb row ski, Przemyst spirytusowy w Królestwie Polskim. Cz. 1: Organizacja, rozwój i stan przemystu spirytusowego $w$ Królestwie Polskim. Warszawa 1918.

$4 \quad$ W kopii maszynopisowej zdanie pominięte.

Maria z G ór s ki c h hr. S obań s ka (1861-1951), córka Konstantego Górskiego i Julii z książąt Golicynów, żona Kazimierza Sobańskiego, działaczka społeczna, charytatywna i niepodległościowa. W latach 1910-1915 była działaczką Związku Stowarzyszenia Spożywców „Społem” (z którym współpracowała także Dąbrowska), a w latach następnych, do r. 1918, organizatorką opieki nad polskimi jeńcami i uchodźcami z Rosji, za co w r. 1916 została w Piotrogrodzie na krótko uwięziona przez władze carskie. Po śmierci męża jej mieszkanie przy ul. Kredytowej 3 stało się znanym salonem warszawskim, w którym bywali ludzie nauki, artyści i pisarze. Dąbrowska poznała ja 
w 1912 roku. Jak wynika z listów Sobańskiej, wcześnie dostrzegła ona talent przyszłej autorki Ludzi stamtad.

5 Huta-Dąbrowa - huta szkła, założona w 1824 r. w województwie lubelskim w powiecie łukowskim w gminie Krzywda. W okresie międzywojennym stanowiła własność spółki akcyjnej z akcjami ulokowanymi w Banku Zachodnim w Warszawie. Na ten czas przypadł największy jej rozwój: zatrudniała około 1000 robotników. W Dziennikach Dąbrowska zapisała pod datą 17 VIII 1928: "Wczoraj zwiedzałam tu hutę "Dąbrowę", nędzną osadę, leżącą w oceanie podolskich piasków. Zrobiła na mnie wielkie wrażenie. Kiedy się widzi więcej ludzi pracujących przy piecach nawet w tak nędznej hucie jak ta - człowiek od razu widzi, że wszystko, co się najokropniejszego na świecie dzieje, jest możliwe i usprawiedliwione” (Dz. t. 2, s. 28).

6 Ewelina Dalecka, siostra Wandy, pisarki.

7 Szulc-Holniccy mieli syna Jana i córkę Anielę (Dzidzię), zamężną z Karolem Hil c h e n e m (zginął w czasie powstania warszawskiego w 1944 roku).

8 W odpisie maszynopisowym listu akapit pominięty.

\section{Maria Dąbrowska}

Kochany -

nie gniewaj się, że Cię zaniepokoiłam telefonem. To wynik napadającego mnie niskiego ataku barbaryczno-histerycznych niepokojów, których podkładem jest chorobliwa plastyczna wyobraźnia. Teraz już czegoś uspokoiłam się o Ciebie i o wszystko. Pobyt tutaj ${ }^{3}$ znakomicie mi robi, tak jak się nawet nie spodziewałam. Piszę trzecią nowelę, pracuję nad nią ze zdumieniem, skąd mi się wzięła. Jest całkowicie wymyślona, czy też ujrzana w wyobraźni, osnuta na wątku zaledwie zasłyszanych faktów, za temat ma, o dziwo, księdza i wychodzi w końcu jakby na apoteozę złego księdza ${ }^{4}$. Zdaje mi się, że to, co mnie szarpie, to doszukiwać się we wszystkim tego ziarenka wiekuistego, dręczonego tęsknotą i miłością, człowieczeństwa. Najtrudniej mi poszło z Bibliotekarką i Oktawią, gdyż są mi zbyt strasznie [!] obce $^{5}$, a jednak pociagały mnie jako zadania, które może chybiłam. Oktawia jest też najczarniejszą stroną mojego tu pobytu. Poczciwa wobec mnie niesłychanie, ale jakże męcząca, nudna, gdybym była Zygmuntem Prz[emyskim] $]^{6}$, strzeliłabym sobie w łeb albo uciekła gdzie pieprz rośnie. A jednocześnie w jakiejś płaszczyźnie potrzebna, pożyteczna - dla mnie w tej chwili po prostu dobroczynna. Jakaż to straszna niedola - nie być w stanie wzbudzić drgnienia niczyjego serca.

Byłam tu któregoś dnia w Oliwie. Dzień był niewymownie ciepły i błogi, chodziłam po przecudownym starożytnym parku, typowym pięknym parku z XVIII stulecia $-z$ pałacem barokowym, $z$ aleja strzyżonych $w$ szpaler jak w Wilanowie niebotycznych grabów i z pasmem czarownie błękitnego morza na końcu tej alei. Sa tam nadto w owym parku tak orgiastyczne masy cudownych kwiatów, jakie widziałam jedynie tylko chyba w Hampton Court pod Londynem ${ }^{7}$. Park ten usposobił mnie do marzeń.

Wracając, byłyśmy ${ }^{8} \mathrm{w}$ Sopotach, gdzie jest imponujące, wielkie molo, tak że się wchodzi daleko na morze. Morze we dnie ciemno-modre, wyraziste i niespokojne, stało się o zachodzie jakby powierzchnią najpiękniejszych opali. Trudno tę grę światła słowami opowiedzieć. 
Wczoraj ciotka Gałcz[yńska] powiozła nas ich autem na Oksywie, a więc wokoło całego portu. Można sobie nie wiem, co mówić, ale roboty, które tu zrobiono, czynią potężne wrażenie. Sa już trzy wielkie baseny wewnętrzne - jeden $z$ nich kończy się daleko, daleko od brzegu, śród łąk, i wielki morski okręt, stojący śród tych łąk na wątłym pasemku wody, uczynił na mnie niesamowite wrażenie. Potem z góry, ze starego cmentarza na Oksywiu widziałam port wojenny, z okrętami, w przeciwieństwie do czerwonego portu handlowego i białego pasażerskiego - szarymi jak z ołowiu. Przypomniały mi Dover, gdzie przed laty takie same torpedowce oglądałam $^{9}$. Potem, wracając, skręciłyśmy na szosę do Kartuz, a choć okolice najbliższe Kartuz znałam, ale usta otwarłam ze zdumienia, gdy ujrzałam, że o dwa kilometry od morza zaczyna się cudowny zupełnie podgórski krajobraz - zupełnie Jaworzański $-z$ dolinami zadumanymi, $z$ samotnymi mgiełkami w głębiach leśnych, $\mathrm{z}$ lesistymi zboczami wyniosłymi. Tak mi się na ten widok zrobiło tęskno do Jaworza. Coraz więcej myślę o wzięciu stałej pracy od listopada - gdybyśmy mogli jeszcze na październik jechać do Jaworza, wyzyskałoby się dobrze te ostatnie tygodnie swobody. Jestem w połowie czytania „Les Marges. Presse et littérature”, czytam z ogromnym zajęciem - i bardzo mi się to stanowisko podoba, gdyż jest podobne do mojego ${ }^{10}$. Nie potępia zjawisk współczesności, ale je wyjaśnia, usiłuje zrozumieć, związać z całością dziejów - znaleźć w nich to lub owo dobrego, nie szczędząc prawdy złemu. Jedno $z$ charakterystycznych zdań jest następujące: „La science est un danger pour la religion; et par conséquence la science est utile à la religion, qui doit sortir purifiée de l'épreuve. Et de même en dépit des apparences mauvaises, la presse ne tuera pas la pensée, que rien ne peut tuer. - Mais la presse est un danger pour la pensée et d'autre part il y a dans ce danger les éléments d'une purification et d'un progrès"11.

Na razie kończę. Napiszę tylko jeszcze jeden list, gdyż we wtorek lub w środę wrócę. Całuję mocno

Twoja

Ma

[Dopiski:]

Listów najmilszych miałam dwa. Spodziewam się jeszcze jednego i może kartki. O powrocie do domu myśle jak o nowej, czekającej mnie rozkoszy.

List bez koperty; rękopis. BUW, sygn. 1564, k. 46-47.

1 Numer dopisany ręką Stempowskiego. Wcześniejsze listy Dąbrowskiej nosiły daty: 12 IX 1929 , 15 IX 1929, 16 IX 1929; tylko trzeci z nich ma numer, ale został on dopisany przez Stempowskiego.

2 Dzień tygodnia dopisany ręką Stempowskiego.

3 Od 25 IV do 4 V 1929 Dąbrowska przebywała na zaproszenie kuzynki, Stelli Dziewulskiej, w jej letnim domu w Gdyni.

4 Mowa o opowiadaniu M. Dą brow s ki ej Ksiądz Filip („Pamiętnik Warszawski” 1929, z. 4. Przedruk w: Znaki życia. Warszawa 1938). W Dziennikach pisarka notowała pod datą 26 IX 1929: „Ja jestem w dobrym usposobieniu ducha. Czuję się zdrowa i odzyskuję dawną ciekawość do świata i życia. $Z$ pisaniem jestem źle, ale nie tracę nadziei. Cały mój pierwszy tom powieści jest do niczego. Przerwałam pracę nad tym, piszę nowele. Jeśli wrócę do powieści, będę musiała to nieomal na nowo napisać. Pierwsza nowela mi się nie udała, druga lepiej” (Dz. t. 2, s. 110).

5 Pierwowzorem bohaterki opowiadania Bibliotekarka (inne tytuły: Czytelnia, Inteligentka, ostatecznie: Panna Winczewska) była pracownica Biblioteki Wojskowej im. M. Dąbrowskiego na Cytadeli 
warszawskiej. Opowiadanie Oktawia oparte zostało na losach wspomnianej w liście Stelli z Leszczyńskich Dziewulskiej; ukazało się ono dopiero w 1938 w tomie Znaki życia.

6 Zygmunt Przemyski - jego pierwowzorem był Leon D zi e w u ls ki, bankowiec, mąż Stelli z Leszczyńskich.

7 W lipcu 1913 Dąbrowska otrzymała od Rafała Radziwiłłowicza propozycję 8-miesięcznego stypendium Towarzystwa Kooperatystów na wyjazd do Londynu dla zbadania zagadnień spółdzielczości w Anglii; dawało to możliwość dłuższego przebywania z mężem, działającym w stolicy Anglii jako komendant Związku Walki Czynnej i mąż zaufania Komisji Skonfederowanych Stronnictw Niepodległościowych.

8 W wycieczce autem Dziewulskich wzięy udział także ciotka Dąbrowskiej, Julia z Gałczyńskich Leszczyńska i jej córka Stella Dziewulska.

9 W pierwszej połowie lipca 1914 Dąbrowska wyjechała ponownie do Anglii, by spędzić kilka tygodni urlopu z mężem. Jej marszruta podróżna obejmowała Berlin, Ostendę, port Dover, wypoczynkowe Folkestone i Londyn. 29 VII, wobec groźby wybuchu wojny, rozpoczęła podróż powrotną do kraju. Mowa o wydanym w lecie 1929 we Francji, pod redakcją E. M o n t f o r ta, czasopiśmie „Revue Les Marges. Presse et Litterature" i o ogłoszonym tam artykule M. P uy oraz o wstępie. Notatki i obszerne cytaty $\mathrm{z}$ artykułu, a także wypisy ze wstępu Montforta zachowały się w archiwum M. Dąbrowskiej w Muzeum Literatury w Warszawie (M. D ą b row s ka, Notatki i wypisy z dziet historycznych $i$ innych lektur, sygn 2037, k. 1-8).

11 „La science est...” (franc.) - „Nauka stanowi niebezpieczeństwo dla religii, a więc nauka jest użyteczna dla religii, która musi wyjść z tej próby oczyszczona. Podobnie, wbrew złym pozorom, prasa nie zabije myśli, której nic nie może zabić. Prasa stanowi jednak niebezpieczeństwo dla myśli, choć $z$ drugiej strony niebezpieczeństwo to zawiera elementy oczyszczenia i postępu" (przeł. A. Trznadel-Szczepanek).

\section{Maria Dąbrowska}

[Jaworze,] Niedziela, 20 X [19]29

Najmilszy Stasiuniu,

Dziś rano wysłałam do Ciebie kartę, w której na boku dopisałam „przyjadę zapewne we wtorek". Było to po nocy, przez którą wiał wiatr halny, rano wstałam taka smutna i przygnębiona, że mi się nie wydawało możliwe dzień jeszcze tutaj przeżyć. I tak zapragnęłam jak najprędzej Ciebie zobaczyć. Potem jakoś opamiętałam się, naturalnie już po wysłaniu karty - i w dalszym ciagu zatem, proszę, czekaj mnie w piątek 25-go, tym pociagiem przyjadę, którym zawsze wyjeżdżaliśmy z Jaworza, co przybywa do Warszawy coś koło czwartej po południu. Gdybym zaś miała przyjechać wcześniej, co nie jest wykluczone, to w środę lub wtorek zadepeszuję. Możliwość zaś przyjazdu wcześniejszego będzie zależała od tego, jak prędko i czy zdołam wykonać pewien program, który mi wczoraj przyszedł do głowy. Otóż więc, ponieważ do czegoś nowego na dobre trudno mi się będzie zabrać, mając tylko kilka dni przed sobą, i ponieważ z naszego miłego niemrawca doktora nic się, poza parogodzinnym spacerem, nie da wycisnąć, postanowiłam na własną rękę zobaczyć niektóre rzeczy, na które tak dawno się zbieram. Jutro więc zamierzam telefonować do Okołowicza ${ }^{1}$, czy może mi pokazać jaką kopalnię lub hutę - jeżeli tak, to zaraz bym pojechała do Katowic.

Myślę, że tam wszędzie jest jakiś gościnny pokój i że mnie Okołowicz jakoś tam przenocuje - nazajutrz już bym pewno wróciła do Jaworza.

Jeżeli $z$ projektu tego nic nie wyjdzie - w takim to razie wrócę wcześniej chyba, gdyby się tu z obecnymi gośćmi ułożyła jakaś większa wycieczka w góry, 
to może bym się jeszcze skusiła. W każdym razie ostateczny termin powrotu piątek.

Dziś poszłam na nabożeństwo ewangelickie i żałuję, że nie poszliśmy kiedyś na nie razem $z$ Tobą, boć to osobliwa okazja zobaczyć cały kościół rdzennych polskich chłopów i niekatolików. Muszę się przyznać, że byłam pierwszy raz na ewangelickim nabożeństwie i że mnie o wiele głębiej wzruszyło i o wiele więcej się podobało niż katolickie.

Ja w ogóle, nie należąc w gruncie rzeczy do żadnego wyznania - jestem jeszcze religijna - i w całej rozciągłości znam wzruszenie religijne. Byle mi tylko nie kazali być w jakim kościele, gdyż mnie wzrusza jednako obrzęd każdej religii. Jestem niejako kłusownikiem Bożym, który czyha na Boga po cudzych lasach.

Ale nabożeństwo ewangelickie poruszyło mnie jakby w regionach duszy o kilka pięter wyżej niż katolickie. O ileż bardziej jest ludzkie, o ile więcej tu ufności nabożeństwo jest tu bardziej pozostawione jemu samemu, duchowny jakby tylko ułatwia i poddaje, tak jak to myślał ksiądz Filip ${ }^{2}$ na swym ostatnim nabożeństwie. Kazanie też, aczkolwiek biedny pastor bił sam siebie, bo mówiąc na temat, że ty lko nędza i niedola, i godzina próby prowadzi nas do Boga - nasuwał na myśl wszystkie zwątpienia religijne, ale w każdym razie mówił jak człowiek, nie jak kretyn, nie było tam banialuków, było to na jakimś poziomie.

A nade wszystko taka moc śpiewu, i to pięknego, który czyni z tego nabożeństwa jakąś poważną, żałosną zadumę, i jeżeli może katolickie ma dla wierzacych w swej zmysłowości coś radosnego, to daje jakieś przejmujące obcowanie z żałością, ze smutkiem kosmicznym, $z$ tragizmem życia.

Przede mną siedziały dziewczyny z otwartymi przed soba psałterzami. Czytałam przez ich ramiona i zwłaszcza podobał mi się jeden psalm, który zaczynał się tak:

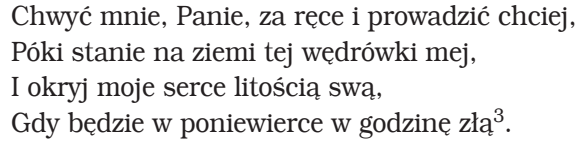

Muszę sobie koniecznie taki psałterz kupić. Zobaczyłam, że jest pisany piękną polszczyzną, choć przeważnie tłumaczony z niemieckiego.

Dziś po tym halnym wietrze nagle zrobiła się jesień, wszystko stało się złote i rumiane - lasy bukowe wyjawiły się na koniec spomiędzy świerków i okazało się, że okrywają znaczną część wzgórz.

To chyba wszystko.

Całuję i do widzenia

Ma.

[Dopisek ołówkiem:] Wtorek 22/X. List ten wysyłam z drogi do Okołowicza. Z Katowic zadepeszuję albo zatelefonuję.

List bez koperty; rękopis. BUW, sygn.1564, k. 61.

1 Alfred Okołowicz (1890-1959), inżynier, w latach dwudziestych XX w. prezes Okręgowego Urzędu Ziemskiego w Katowicach. W roku 1955 odznaczony Medalem 10-lecia Polski Ludowej. Dąbrowska poznała Okołowicza w r. 1918, gdy rozpoczęła pracę w Ministerstwie Rolnictwa i Dóbr Państwowych.

2 Mowa o bohaterze opowiadania Dąbrows ki ej Ksiadz Filip. 
Pieśń autorstwa J. K. Ha u s m a n n, o incipicie „So nim denn meine Hände” (powst. ok. 1862), w polskich anonimowych przekładach znana jest w kilku istotnie różniących się wariantach, innych niż tekst zapamiętany przez Dąbrowską. Wersja opublikowana w Śpiewniku pielgrzyma (wyd. 3, przerobione. Dolny Żuków 1935, s. 322-323; wyd. 1 i 2 nie zachowały się) brzmi następująco:

1

Za ręce bierz mnie, Panie, i prowadź mnie, Bym wiecznie w błogim stanie wysławiał Cię! Ni kroku ja bez Ciebie nie mogę iść;

Sam wesprzyj moją nogę, swe słowo ziść!

2

Posilże miłosiernie me serce mdłe;

Niech w złym i dobrym wiernie zachowa się! Niech spocznie dziecię Twoje u Twoich nóg; Okażże miłość swoją, Tyś jest mój Bóg!

3

A choćbym Twojej mocy nie uczuł raz, Ty wiedziesz i wśród nocy do celu nas. Za ręce bierz mnie, Panie, i prowadź mnie, Bym wiecznie w błogim stanie wysławiał Cię!

\section{Stanisław Stempowski}

[Warszawa,] 8 V 1930

Powróciwszy z biura, skąd napisałem Ci kartkę w sprawach domowych, „folwarcznych", jak gadał Żeromski, zastałem w domu Twój list ${ }^{1}$. Tak mi zajechałaś tym swoim durnym Pascalem ${ }^{2}$, że zamiast położyć się spokojnie na łonie przyjaznym ludwikowym, zasiadam żeby Ci odpowiedzieć.

L'incertain Pascalowskie ${ }^{3}$ nie ma w danym wypadku (Pończa) ani w ogóle dla człowieka i jego spraw na ziemi żadnego znaczenia (chyba dla kapłanów i znachorów wszystkich religii świata, którzy na tej niepewności i niewiadomości żerują i pasą się, strasząc nią biednego człowieka, bądź bezpośrednio, bądź przez różnych dobrowolnych komiwojażerów, jak Chesterton ${ }^{4}$. Jeżeli ja nie wiem, to i oni nic nie wiedzą, i nikt nie wie - więc po cóż nawracają, biją w dzwony, ponukają ${ }^{5}$ państwo do przemocy, święcą oręż, sieją zabobon - i biorą za to pieniądze. Ale mniejsza o to. Nieprawda jest, qu'il ne vaudrait rien faire du tout car rien n'est certain ${ }^{6}$. Żyjemy, cieszymy się życiem, smucimy, działamy i rozpaczamy, kochamy i nienawidzimy, projektujemy na najdalszą przyszłość i nagle umieramy - niezależnie od tego, czy jesteśmy „nieśmiertelni”, i nawet, co najważniejsza, czy mamy tego poczucie, czy wiarę. Tak samo jak istniejemy niezależnie od tego, czy jest czas, przestrzeń, przyczynowość, ciążenie i inne mętne i piękne koncepcje, mające swe źródło w potrzebie ducha ludzkiego do ujmowania świata w prostocie i ładzie. I to jest dziedzina właśnie owego wiekuistego incertain jedynie w postaci chyba luźnego urozmaicenia stykającego się z życiem. Ale życie (dla którego nie ma określenia [innego niż] la vie, c'est la vie - [jak] powiada Guyau ${ }^{8}$ ) i jego sprawy niepewności nie znosza. Nawet śmierć, czyli zaprzeczenie życia, jest pewnością, która mu nie wadzi, lecz potęguje jego poczucie. Bo o śmierci tylko w i e my (dziedzina incertain'u), ale jej w s o bi e nie mamy do ostatniego tchnienia. Nie wiemy, jak jest w tzw. przyrodzie, gdzie życie ukazuje się nam jako potężne parcie do ekspansji (horret vacui ${ }^{9}$ ), pełni, rozwoju, utrwalenia w zmienności i znikaniu. Zapewne tak samo, jak w świecie ludzkim, kiedy spojrzeć nań masowo, jak się zachowuje wśród kataklizmów - po- 
moru, wojny, trzęsienia ziemi, w zapadającej w otchłań Martynice lub Messynie. Włoch, obejrzawszy ślady życia „do ostat[niej] chwili” w Herkulanum, sadzi winnice na zboczu wulkanu, jak mrówka nie zwraca uwagi na depcząca ją naszą stopę.

A chodzi nam przecie o samotnego człowieka. O nim właściwie chciałem mówić, a wdałem się w powyższe naiwne konsyderacje, $z$ których się zawsze śmiejesz. Otóż o człowieku. Każdy przejaw jego życia, od rannego wciagania butów do czynu najwznioślejszego bohaterstwa, ufundowany jest na niezachwianej (przez wszystkich Pascalów świata) pewności, na którą składa się: skupione w nim doświadczenie ży ci ow e zmarłych pokoleń (instynktu w dziedz[inie] fizjologicznej, automatyzm psychicz[ny] czy intuicja w dziedz[inie] „duchowej”, dunkle Drang ${ }^{10}$ w moralnej), oraz wła s ne doświadczenie przeżyciowe. To ostatnie, które jest czymś w rodzaju osobistej religii (nie zawsze i nie w całości pokrywającej się $z$ tzw. wierzeniami religijnymi), zakreśla zupełnie pewne i niezłomne granice i możliwości naszych czynów, naszego życia. Wy, artyści, nic innego nie robicie, jak właśnie krążycie wciąż dokoła tej ukrytej tajemniczej spreżzyny w człowieku, która jest kluczem do pochwycenia typu. Nostromo, Korsarz, Marlowe, Don Kichot tak samo z nieomylną pewnościa snują swój żywot, jak jemiołuszka swoje misterne gniazdo. I to pewne w człowieku, które określa jego istotę i determinuje jego typ, a do pewnego stopnia i los, jest jedynie ważne (i dla artysty ciekawe), a reszta - tj. incertain - to dym.

$10 \mathrm{~V}$ [1930], sobota

Miła moja,

Napisałem na gorąco jakieś niemądre rzeczy, ale nie chcę tego niszczyć, niech będzie dla pamięci znak, że rozmyślałem nad Twoim listem. Piszę już po śmierci Pończa. Gdybym umiał pisać, to bym po tych kilku dniach mocnych i głębokich przeżyć zatargał trzewiami ludzi. Pozostał mi list Zabojeckiej ${ }^{11}$, którym kiedyś cisnę w morde „narodu” polskiego, trzymającego się kurczowo sutanny ${ }^{12}$. List ten $\mathrm{Ci}$ przyślę w odpisie. Dziś, chociaż cały dzień nie wychodzę, wiszę przy telefonie i jak kapitan miotanej przez burze nawy odbieram relacje i wydaje polecenia. Za to mam dziś poczucie, że udało mi się rozwiązać kwadraturę koła, i to polskiego. Bo posłuchaj.

Dziś rano przez Łask koleją do Łodzi przewieźli pepeesi trumnę - tam do wieczora mieli robotnicy łódzcy, do których tylokrotnie przemawiał, uczcić go po swojemu. Jutro rano przybędą zwłoki na rampę do Warszawy, skąd powiezione zostaną do Domu Kolejarza (gdzie teatr „Ateneum”) i w sali wystawione dla publiczności. Przy niedzieli możesz sobie wyobrazić, jakie tłumy oddadza mu hołd. (Mnie cieszy to, że będzie wyżłobiona tradycja i już nikt odtąd, mając ten Dom, nie będzie zależny od żadnych Kościołów i upokarzających wydziwiań.) Daszyński aż za głowę się schwycił, że nikomu to nie przyszło na myśl, kiedy chowano Perla i musiano oddać go żydowskim wyjcom ${ }^{13}$. I to był mój wynalazek: jedno słowo wpisane do aktu zejścia oraz wyspa kalwińska, która odtąd będzie eksterytorialnym przybytkiem dla zbiegów od religii. W poniedziałek o 4 1/2 pogrzeb na Młynarskiej...

Przy pomocy Czekana ${ }^{14} \mathrm{i}$ Wichuny ${ }^{15}$ sprawiłem potwornych rozmiarów wieniec $\mathrm{z}$ gałęzi świerkowych $\mathrm{z}$ dwiema potworn[ymi] szerokimi wstęgami - białą i purpurowa - i napisem: „Redaktorowi "Ogniwa" - współpracownicy”. Zebrałem telefonicznie garstkę ich. Nie przypuszczałem, że już nas tak niewiele zostało. Ten znak 
byłby Pończowi najmilszy, gdyby Twój Pascal miał rację. (Dla mnie wystarcza p ew no ść, że to jest wyraz mojego ,ja”, mojej tożsamości.)

Miałem i list od Zosi ${ }^{16}$, b[ardzo] przyjemny, pełen prostoty. Też Ci odpisze. Stwierdzam radośnie tkliwą współpracę wszystkich, do których się odwołuję i z którymi rozmawiam telefonicznie. Widzę, że Pończ nie miał niechętnych, że miał miłość ludzka, którą sam siał dokoła często w sposób niezdarny i nawet śmieszny. Dziś śmieszności opadły jak pył - a zostało czyste obnażone serce. (I stwierdzam jeszcze, że Czekan ma właściwość zjawiania się wszędzie tam, gdzie jest potrzebny. Tego też w zniecierpliwieniu często nie dostrzegałem.)

wieczór

Miałem telefon $z$ „Polonii”. Lucjanostwo ${ }^{17}$ przybyli tu samochodem i tam ulokowali Zabojecką wraz z jej towarzyszką. Jutro rano ma być tu Lucjan i razem odwiedzimy siostrę.

Tyle Ci nabazgrałem, że już na nasze sprawy nie ma miejsca. Wczoraj był telefon od Kazia ${ }^{18}$, kazał pozdrowić Cię. Dziś telef[onował] kpt. Pomarański ${ }^{19}$ prosząc o przysłanie mu (Ratuszowa 12 m. 13 na Pradze) 1) krótkiej biografii Mariana ${ }^{20}$, 2) wykazu jego książek i ważn[iejszych] artykułów w pismach, 3) wykazu wspomnień o nim. Podobno mu to obiecałaś. Może mógłbym $z$ Wackiem ${ }^{21}$ Cię zastapić?

Władzia prosi o podziękowanie Ci za list, nad którym się spłakała i ma zawieźć rodzinie.

Całuję Twoje ręce za to, że piszą pracowicie, co głowa pomyśli. Pisz, pisz!

St.

List Jadzi ${ }^{22}$ musiałem wyjąć $\mathrm{z}$ koperty, bo dużo ważył, ale nie czytałem.

List bez koperty; rękopis. BUW, sygn.1389, k. 21-22.

1 Chodzi o list z 5 V 1930.

2 Dąbrowska, poruszona śmiercią S. Posnera i okolicznościami jego pogrzebu, pisała:

„Szczęśliwy jesteś, a może biedny, że tak na pewno możesz wszystko w tej dziedzinie twierdzić. Powiadasz: "dla Poncza, skoro już o tym nic wiedzieć nie będzie nigdy" - jest to rzecz obojętna. Skąd naprawdę my mamy możność mówić o tym tak pewnie, gdy nawet w obrębie naszych zmysłów wszystko jest tak niepewne i skoro właśnie wszystkie nasze uczynki i kroki stosujemy do tego, że może to jest tak, a może inaczej. Pascal powiada o tym tak:

"S'il ne fallait rien faire que pour le certain, on ne devrait rien faire pour la religion, car elle n'est pas certaine. Mais combien de choses fait-on pour l'incertain, les voyages sur mer, les batailles! Je dis donc qu'il ne faudrait rien faire du tout, car rien ne'est certain. [...] Or quand on travaille pour demain et pour l'incertain, on agit avec raison"” (B. P a s c a 1, Pensées sur la religion et sur quelques autres sujets. Paris 1669. Nawiasem kwadratowym zaznaczono fragment pominięty przez Dąbrowską).

W przekładzie T. B oy a-Żeleńs ki e go (B. Pa s c a 1, Myśli. Warszawa 2008, s. 130-131〈Dział trzeci: O konieczności zakładu〉) fragment ten brzmi:

„Gdyby należało coś czynić jedynie dla pewności, nie powinno by się nic czynić dla religii: nie jest pewna. Ale ile rzeczy robi się dla tego, co niepewne: podróże morskie, bitwy! Twierdzę tedy, że nie trzeba by nic czynić w ogóle, nic bowiem nie jest pewne. [...]. Otóż pracując dla jutra i dla rzeczy niepewnych, czynimy słusznie".

3 „L'incertain” (franc.) - „niepewność”. Stempowski miał zapewne na myśli tzw. „zakład Pascala”: „Tak, ale trzeba się zakładać; to nie jest rzecz dobrowolna, zmuszony jesteś. Cóż wybierzesz? Zastanów się. Skoro trzeba wybierać, zobaczmy, w czym mniej ryzykujesz. Masz dwie rzeczy do stracenia: prawdę i dobro; i dwie do stawienia na kartę: swój rozum i swoją wolę, swoją wiedzę i swoją szczęśliwość, twoja zaś natura ma dwie rzeczy, przed którymi umyka: błąd i niedolę. Skoro trzeba koniecznie wybierać, jeden wybór nie jest z większym uszczerbkiem dla twego rozumu niż drugi. To punkt osądzony. A twoje szczęście? Zważmy zysk i stratę, zakładając się, że Bóg jest. Rozpatrzmy 
te dwa wypadki: jeśli wygrasz, zyskujesz wszystko, jeśli przegrasz, nie tracisz nic. Zakładaj się tedy, że "jest", bez wahania” (P a s c a l, Myśli, s. 127 〈Dział trzeci: O konieczności zakładu〉).

Gilbert Keith Che ster ton (1874-1936), angielski pisarz katolicki, głosił w twórczości potrzebę optymizmu moralnego i afirmacji życia. W młodości był agnostykiem, z czasem doszedł do dojrzałej wiary chrześcijańskiej. Włączył się w nurt odnowy duchowej Kościoła anglikańskiego, w r. 1922 przeszedł na katolicyzm. Swoją drogę do poznania wiary opisał w książce Ortodoksja. Romanca o wierze (1908).

6 „Qu'il ne vaudrait rien faire du tout car rien n'est certain” (franc.) - „że nie trzeba by nic czynić w ogóle, nic bowiem nie jest pewne” (P a s c a l, Myśli. s. 130 〈Dział trzeci: O konieczności zakładu〉). „La vie, c'est la vie” (franc.) - „życie to jest życie”.

8 Jean Marie Guyau (1854-1888), francuski pisarz i filozof, przedstawiciel filozofii życia, które pojmował jako organiczno-duchowy fundament sztuki, moralności i religii, mający ekspansywny charakter, przy zachowaniu nieusuwalnego instynktu moralnego. Głosił koncepcję ewolucjonistycznej etyki, w której hedonizm łączy się z altruizmem, moralność nie potrzebuje sankcji, a religia zostanie w przyszłości zastąpiona powszechną miłością. Opublikował La Morale anglaise contemporaine (1873), Zarys moralności bez powinności i sankcji (1885, wyd. polskie: 1910), L'Irréligion de l'avenir (1887), Zagadnienia estetyki wspótczesnej (1884, wyd. polskie: 1901).

9 „Horret vacui” (łac.) - „nie znosi próżni”; parafraza łac. „horror vacui” ('lęk przed próżnią’; „, natura horret vacuum" - 'natura nie znosi próżni').

10 „Dunkle Drang” (niem.) - „ciemny pęd”. Nawiązanie do Fausta J. W. G o e th e go (Prolog w niebie, 328): „Ein guter Mensch, in seinem dunklen Drange, / Ist sich des rechten Weges wohl bewusst” „Człek [...] w ciemnym swym pędzie / Jest mimo wszystko prawej drogi świadom” (przeł. F. Konopka).

11 Maria Zabojecka, właśc. Malwina Garfeinowa-Garska, z domu Posner (1872-1932), siostra Stanisława Posnera; pseudonim literacki Maria Zabojecka w 1921 r. urzędowo przybrała za nazwisko. Pisarka, krytyk literacki, tłumaczka. Popularyzowała nowe prądy literackie, opowiadała się za sztuką związaną z życiem społecznym i politycznym. Opublikowała m.in. Powieść o duszy polskiej (1910), przedstawiająca dzieje polskiej martyrologii od XVIII w. po powstanie styczniowe. Przekładała głównie z literatur skandynawskich. Stempowski znał Garfeinową od czasów pracy w „Prawdzie” Świętochowskiego. Gdy w 1902 r. w czasie redagowania „Ogniwa” przyjechał do Krakowa, Zabojecka, bliska współpracowniczka tego pisma, wprowadziła go do środowiska radykalnych literatów. Wspominając w Pamiętnikach trudny charakter Posnera, S. S t e mpow s ki (Pamiętniki 1870-1914. Wrocław 1953, s. 277) pisał: „Wytrzymały z nim do końca jedynie trzy istoty: siostra Garfeinowa, Lucjanostwo Niemyscy i ja. Siostra, bo siostra, pełna była egzaltowanej miłości do genialnego brata i w tej egzaltacji, sama opuszczona i nieszcześliwa, znosiła ofiarnie od niego wszystkie udręki. Nawet po śmierci brata poświęciła się, przyjmując obcy jej protestantyzm (gdyż ciążyła ku katolicyzmowi), żeby ocalić jego grób”.

12 Mowa prawdopodobnie o liście M. Zabojeckiej z 9 V 1930, w którym pisała ona m.in.: „Kochany Panie Stanisławie, zgasło to najdroższe życie, nie ma go już wśród nas. Nie ma go - może Pan to pojaćc? Ale to już sprawa moja, a teraz trzeba uczynić wszystko tak, jak pragnął, aby ta całożyciowa męka Jego, że wbrew wszystkim ukochaniom swoim, z przypadku urodzenia nazywał się Żydem i wbrew woli i wiarom do tej żydowskiej należał z pozoru gminy, aby męka ta wreszcie była skończona, aby był bodaj za cenę śmierci tym, czym był istotnie. Pan wie i nieraz mówiliśmy o tym, że chciał on najoficjalniej wyjść z tej gminy, prosił nawet Panią Basię [Poniatowską, aby go pochowała w ich rodzinnym grobie. Chciał tak bardzo leżeć na Powązach. To pozostanie pewnie tylko marzeniem, gdyż na to potrzeba by przecież było, aby przyjął katolicyzm, On zaś katolikiem nie był tak samo, jak nie był Żydem, i za nic nie stanąłby pod ochroną kłamstwa. Trzeba iść po linii jego wewnętrznej, stał zaś po tamtej stronie wszelkich oficjalnych wyznań i tak Go trzeba pochować. Nie wiem, jakie muszą być dokonane formalności, Pan jednak, który jak nikt znał ten jego ból bólów, tragiczną rysę, jaka szła przez całe Jego życie, na pewno tak wykona jego wolę, aby po jego śmierci nie rościły sobie do niego prawa żadne Kościoły, aby nie wyli nad nim żadni księża lub rabini. Gdyby czysta formalność przejścia na katolicyzm nie była dla jego subtelnego poczucia prawdy z prosta kłamstwem, byłby tej formalności dokonał. $Z$ całej tej męki swojej zwierzył się przed śmiercią Pani Basi i gdy już prawie nie mówił, może na trzy godziny przed śmiercią, wyrzekł 
z trudem, ale wyraźnie do Pani Basi: "nie chcę być na żydowskim cmentarzu pochowany" - powiedział wszystkim. Panie Stanisławie, błagam, żądam, aby ta wola brata mego co do litery była wykonana. Prośba jego do Pani Basi, aby Go pochowała w ich grobie, już nawet była jakby zgodą na chrzest, ale ci czyści, tak wyjątkowo czyści ludzie nie chcieli zmącić jego prawdy bodaj pozorem jakiegoś kompromisu lub kłamstwa. Proszę kochanego Pana, niech Pan ws zy st ko czyni tak, aby Go już śmierć pokrzywdzić nie mogła”. (BUW, rkps 1559, k. 92).

13 Feliks Perl został pochowany na Cmentarzu Żydowskim przy ulicy Okopowej w Warszawie. W uroczystościach uczestniczyli m.in. Aleksandra Piłsudska, Stanisław Wojciechowski, Maciej Rataj, Walery Sławek, Andrzej Strug i Wacław Sieroszewski. Nad trumna przemawiał Mieczysław Niedziałkowski. Pogrzeb stał się wielką manifestacją, w której wzięły udział tysiące robotników.

Czekan - Stanisław Czekanowski (1868-1963), przyrodnik, agronom, działacz społeczny i samorządowy, wolnomularz, najbliższy przyjaciel Stempowskiego od czasu studiów w Dorpacie. W okresie gimnazjalnym brał udział w ruchu niepodległościowym i socjalistycznym. Działał w organizacjach rolniczych, w latach 1927-1933 był wyższym urzędnikiem Ministerstwa Rolnictwa, w latach 1933-1944 z nominacji ministra - prezesem Hrubieszowskiej Fundacji im. S. Staszica, a w r. 1933 także komisarzem Izby Rolniczej Kieleckiej i Wołyńskiej. Po wojnie pracował jako naczelnik Wydziału Nasiennego Urzędu Wojewódzkiego w Szczecinie.

15 Wichuna - Ludwika Rettingerowa, żona Mieczysława Rettingera, przez przyjaciół nazywana Wichuną. Zaprzyjaźniony z Rettingerami Jerzy Stempowski mieszkał z nimi przy ul. Flory $1 \mathrm{w}$ Warszawie i przez 13 lat z powodzeniem opiekował się bliską jego sercu, chorą na raka p. Ludwiką, kierując jej kuracją.

16 Zofia Poniat ow ska, z domu Po ho sk a (1888-1942), żona Juliusza Poniatowskiego, polityka, ekonomisty, ministra rolnictwa w Polsce międzywojennej. Była przyjaciółką Dąbrowskiej od lat studiów w Brukseli, gdzie obie należały do Stowarzyszenia im. Joachima Lelewela. Po wybuchu drugiej wojny światowej wyjechała wraz z mężem do Rumunii, a po ucieczce $z$ obozu internowania oboje przedostali się przez Turcję do Palestyny, gdzie zmarła. Poniatowscy mieli córkę Barbarę (zginęla w powstaniu warszawskim).

17 Chodzi o Lucjana Niemyskiego i jego żonę. Lucjan N i e m y s k i (1885-1948), bliski znajomy Stempowskiego i Dąbrowskiej, właściciel ziemski, z wykształcenia rolnik. Za pomoc rodzinom żydowskim w czasie wojny Niemyski oraz jego żona zostali odznaczeni medalem „Sprawiedliwy wśród Narodów Świata".

Barbara N i e m y s k a (1883-1955), żona Lucjana, córka Ksawerego Niemyskiego, właściciela Woli Ługuckiej.

18 Mowa o Kazimierzu W i e r zy ń s k i m, którego Dąbrowska znała od 1920 r. i z którym była zaprzyjaźniona.

19 Zygmunt Po marań s ki (1898-1941), żołnierz Pierwszej Kompanii Kadrowej i Wojska Polskiego, księgarz, wydawca, kompozytor, młodszy brat Stefana Pomarańskiego. Należał do Polskich Drużyn Strzeleckich oraz tajnego skautingu. Wraz z bratem Stefanem założył w grudniu 1917 w Zamościu „Księgarnię Polska”, którą następnie prowadził pod firmą „Z. Pomarański i Spółka”.

20 Pomarański wydał w swojej oficynie książkę M. D ą b row s ki e g o Różaniec życia i śmierci. Opowiadania z cyklu „Żotnierz I Brygady”, zebrane na dziesięciolecie czynu legionowego (Łomża 1924; wyd. nast., pt. Różaniec życia i śmierci. Opowiadania: Zamość 1930).

21 Mowa o Wacławie Dabrowskim.

22 Jadwiga Szu m ska (1894-1944), młodsza siostra Dąbrowskiej, nauczycielka gimnazjów. W latach 1920-1937 mieszkała stale w Białymstoku, następnie w Warszawie, gdzie uczyła w gimnazjum im. Królowej Jadwigi. Odznaczona Srebrnym Wawrzynem PAL (1936). W okresie okupacji niemieckiej uczestniczyła w tajnym nauczaniu. Należała do Związku Syndykalistów Polskich. W czasie powstania warszawskiego jako członkini Wojskowej Służby Kobiet była kolporterką biuletynu „Iskra”. Ciężko ranna, zmarła w szpitalu powstańczym przy ul. Mokotowskiej 55. Była prototypem Joanny Tomyskiej w powieści Przygody człowieka myślacego. 


\section{Maria Dąbrowska}

[Jaworze,] $13 \mathrm{~V}$ [19]30

\section{Drogeńki,}

List $z$ opisem pogrzebu Poncza otrzymałam. Jestem po prostu szalenie $z$ Ciebie dumna - jesteś genialny, jak bierzesz się do rozwiązywania konkretnych zagadnień życia i śmierci. Urządziłeś to wszystko i obmyśliłeś wzniośle z patosem - i tak, jak by Poncz chciał to mieć. Ja wczoraj w dzień pogrzebu napisałam listy do Basi ${ }^{1}$ i do p. Zabojeckiej. Włożyłam oba w jedną kopertę i zaadresowałam do Piorunowa, niech już oni pani Zabojeckiej prześlą. Nie wiem tylko, czy oni wrócili już do domu, czy może w ogóle gdzie po tych przejściach wyjechali?

Co do roztrząsań Twoich na temat Pascala to, Kochanie, i Ty masz rację - i on, każde rozumowanie jest tylko próbą uzasadnienia własnego typu duchowego. Ja jestem innym typem, więc czerpię mądrość z innych niż Ty - myślicieli. Wzrusza mnie to pojęcie świata, które jest mojemu temperamentowi i mojej istocie najbliższe. Gdyby Pawełek żył ${ }^{2}$, może by mnie zrozumiał. Ale to nic nie szkodzi, idziemy przecież razem splątani i ku jednemu, choć stanowimy dwa prądy jakby z dwu innych źródeł płynące.

Proszę Cię, wpłać 20 złotych na cel, jaki uważasz za odpowiedni, byle nie partyjny i nie polityczny, i ogłoś to ode mnie w „Robotniku” zamiast kwiatów na trumnę Poncza. Zaś odbierz sobie te 20 zł z honorarium za 20 nr „Kobiety [Współczesnej]”, które w przyszłym tygodniu niech Marysia na potrzeby domu podejmie. Kartkę na to załączam. List od Jadzi mogłeś przeczytać. Rezultaty tutejszej kuracji odbiły się niezwykle korzystnie na malowaniu, które przeszło mi bez żadnej przykrości, jak prawie nigdy.

Całuję Cię, chciałabym już być w domu. Jak robisz z urlopem?

Twoja Ma.

List bez koperty; rękopis. Muz. Lit., sygn. 2050, t. 2, k. 43-44.

Chodzi o Barbarę Niemyską.

Pawełek - najmłodszy syn Stempowskiego, zmarł w 1920 r. w wieku 19 lat.

\section{Stanisław Stempowski}

[Warszawa,] 3 XII [19]31

Myślę, że dojechało się dobrze ${ }^{1}$, ale wiadomości czekam. Tu po powrocie $z$ dworca zastałem trzy listy: od Skiwskiego ${ }^{2}$, że napisze o I tomie, i éloge $e^{3}$ od Tretiaka ${ }^{4}$, że dał żonie do czytania, a sam przeczyta na Wigilię, od Wittlina ${ }^{5}$ zachwyt nad „powaga, prostotą i szlachetnym tonem narracji” pierwszych kilkunastu stron. A dziś przyszła karta od Zawodzińskiego ${ }^{6}$, spodziewającego się „silnych artystlycznych] wrażeń podczas lektury”. Przypuszczam, że takich listów posypie się b[ardzo] dużo i że ich odsyłać do Jaworza nie ma sensu. Będę je wszystkie składał akuratnie i sygnalizował w moich raportach. Czy tak? Gdyby nie tak, to spełnię rozkaz. „Rob[otnik]a” dziś wysłałem, jest tam Struga o przetrwaniu ciemnej nocy narodowej ${ }^{7}$. Grydzo$w i^{8}$ już powiedziałem, że o Prusie pisać nie możesz teraz i dlaczego. Kazia nie mogę jeszcze, ale jutro a może dziś wieczorem to uczynię - żeby korektę $z$ rękop[isu] 
przysłał mnie ${ }^{9}$ - Honorarium $z$ „Kobiety” sute już Władzia odebrała, aż 48 zł $^{10}$, będzie na otarcie jednej łzy, ale czymże inne osuszę? Siedzę nad przecinkowaniem dalszych rozdziałów i jutro rano sam zaniosę na Mazowiecką ${ }^{11}$ sporą porcję rękopisu. Tak samo sam Wóycickiemu ${ }^{12}$ zaniosę podanie rano - już koperta i książki opakowane. Oto moja kroniczka: miałem być dziś u Samiczki na Czerniak[owskiej] ${ }^{13}$, ale nie pójdę. Tak samo nie pójdę na odczyt Doncowa ${ }^{14}$, bo nie dostałem zaproszenia. Za to coś urobię. Wczoraj zgnoił mi wieczór biedny Czekan, który ze stoicyzmem znosi dolę Hioba współczesnego, licytowanego do nagości. Ucieszyłem się rano, zobaczyłem białe dachy - pewnie i w Jaw[orzu] śliczny śnieg wypadł. A kopytka w pantofelkach tylko! Ręce całuję.

St.

[Dopisek na marginesie:] Wszystkim ludziom pozdrowienia. Może co przysłać?

Karta pocztowa, adresowana: „WPani Maria Dąbrowska, Sanatorium Dr. Czopa, Jaworze, (Śląsk Cieszyński)”. Stempel pocztowy: „Warszawa 2 4.XII.31. 11-12; „Kup los państwowej loterii klasowej”. Muz. Lit., sygn. 2071, t. 2, k. 110.

1 Pod datą 27 XII 1931 Dąbrowska pisała w Dziennikach: „Zbyt dużo przeżyłam w ciągu tej jesieni, abym mogła była pisać. Pierwszy tom powieści pod ogólnym tytułem Noce $i$ dnie wyszedł $z$ druku w końcu listopada i doznał niezwykle gorącego przyjęcia, tak że jeszcze zanim ukazała się jakakolwiek recenzja, niemal w ciągu tygodnia rozeszło się 3/4 nakładu, co prawda bardzo małego, bo wynoszącego 2 tysiące egz[emplarzy], ale to i tak podobno na dzisiejsze czasy, kryzys i moje prawie nowe w literaturze nazwisko - rzecz niebywała” (Dz. t. 2, s. 135).

2 Jan Emil Skiwski opublikował w „Wiadomościach Literackich” (1932, nr 6, s. 4) bardzo pochlebne omówienie tomu Bogumił i Barbara zatytułowane Zamiast recenzji. Przedruk w: Na przełaj. Warszawa 1934; Na przełaj i inne szkice o literaturze i kulturze. Kraków 1999.

3 „Éloge” (franc.) - pochwała.

4 Listu A. Tretiaka, o którym pisze Stempowski, nie udało się odnaleźć.

5 List J. Wittli na dotyczący Bogumiła i Barbary znajduje się w Gabinecie Rękopisów BUW (sygn. 1385, t. 11).

6 Karty K. W. Zawodzińskiego nie udało się odnaleźć. W następnym roku Zawodziński wygłosił referat o twórczości Dąbrowskiej na 175 Środzie Literackiej w Wilnie (14 XII 1932; zob. „Dziennik Wileński” 1932, nr z 15 XII), a w r. 1933 opublikował obszerne studium Maria Dabrowska. Historycznoliterackie znaczenie jej twórczości („Przegląd Współczesny” t. 44 〈1933〉, nr 129/130. Przedruk w: Opowieści o powieści. Kraków 1963; Pegaz to nie samochód bezkołowy. Warszawa 1989).

7 33-ci dzień procesu brzeskiego. Andrzej Strug i Kazimierz Czapinski przed stołem sędziowskim. „Robotnik” 1931, nr 425, s. 2-3. Pisarz, jako działacz PPS i uczestnik Kongresu partii w Krakowie, przesłuchiwany był z powodu wywiadu Dopełniły się czasy, przepełniła się miara, jakiego udzielił „Robotnikowi”, w którym - cytując słowa B. Limanowskiego - miał obrazić prezydenta RP. Odpowiadając na pytania adwokatów mówił o dyktaturze w Polsce. Indagowany o uczestnictwo w założeniu Związku Byłych Legionistów-Demokratów wyjaśnił, iż z powodu represji władz zaniechano tej inicjatywy, by nie narażając członków na prześladowania „przetrwać te ciężką noc narodową”. Wypowiedź Struga została ocenzurowana w pięciu fragmentach.

8 Mowa o Mieczysławie Grydzewskim, redaktorze „Wiadomości Literackich”; z pismem tym Dąbrowska współpracowała w latach 1924-1929 i 1930-1939.

9 Jesienią $1931 \mathrm{~K}$. Wierzyński założył w Warszawie tygodnik „Kultura”, który redagował do maja 1932. M. Dąbrowska zamieściła tam fragmenty cz. 3 Nocy i dni zatytułowane Gdzie jesteś? (1931, nr 1) oraz A kiedy odjeżdżasz? (1931, nr 2), a następnie wywiad Jak powstawały „Noce i dnie” (1932, nr 7), jak też fragment Tajemnica Katelby. Rozdział z III tomu „Nocy i dni” (1932, nry 15-16).

10 W roku 1931 Dąbrowska publikowała w „Kobiecie Współczesnej” fragmenty Nocy i dni: Ślub. (Rozdział z powieści „Pośród życia i śmierci”) (nry 8-10) i Wuj Klemens Klicki. (Fragment powieści „Wśród życia i śmierci”) (nry, 11-13). Dalsze fragmenty ogłosiła w następnym roku, już pod ostatecznym tytułem powieści. 
Drukarnia oraz księgarnia wydawnictwa Mortkowiczów mieściły się od 1911 r. przy ul. Mazowieckiej 8; w r. 1913 Mortkowicz kupił nadto Księgarnię Powszechną przy ul. Marszałkowskiej 165.

Kazimierz Wóy cic ki (1876-1938), teoretyk i historyk literatury. Od roku 1917 był wizytatorem szkół średnich Ministerstwa Wyznań Religijnych i Oświecenia Publicznego. Od roku 1925 pracował w Wydziale Programowym Ministerstwa, a od r. 1930 jako naczelnik Wydziału Literatury i Teatru w Departamencie Sztuki, był też członkiem wielu komisji działających przy MWRiOP.

13 Nie udało się ustalić, o kim mowa; osoby o tym nazwisku nie ma także wśród korespondentów Stempowskiego i Dąbrowskiej.

14 Dmytro Don cow (1883-1973), pisarz ukraiński, dziennikarz, działacz polityczny, prawnik, twórca ukraińskiej koncepcji nacjonalizmu, przyjętej w latach trzydziestych XX w. przez Organizację Ukraińskich Nacjonalistów za podstawę ideologiczną działalności politycznej. Postulował całkowite zerwanie więzów politycznych i kulturalnych Ukrainy z Rosją oraz bliską współprace z Europa Zachodnią. W latach 1922-1939 mieszkał we Lwowie, gdzie wydawał pisma „Literaturo-naukowyj wistnyk”, ,Zahrawa” oraz skrajnie nacjonalistyczne i antypolskie „Wistnyk”. Był współorganizatorem Ukraińskiej Partii Pracy Narodowej. We wrześniu 1939 został osadzony w Berezie Kartuskiej, skąd wyszedł po wkroczeniu armii sowieckiej do Polski. Przedostał się do Bukaresztu, następnie do Pragi, w r. 1945 osiadł na stałe w Montrealu, gdzie wykładał literaturę ukraińską.

\section{Maria Dąbrowska}

Kochany,

Dziękuję za trzecią kartkę ${ }^{2}$, rzeczywiście dla mnie bardzo zdumiewająca, tym bardziej, że im dalej jestem od tego pierwszego tomu ${ }^{3}$, ten ${ }^{4}$ wydaje mi się bardziej niedoskonałym. Na to, aby się nie przewróciło w głowie, wystarcza przeczytać coś Conrada. Właśnie przeczytałam tu w „Wiadomościach” ową nowelę Amy Foster i od razu poczułam, gdzie moje miejsce pisarskie. Na słomiance pod drzwiami!! Przeczytaj to, gdyż chciałabym o tym z Tobą rozmawiać. To nowela, którą niewątpliwie musiał napisać po swoim jedynym pobycie w Zakopanem w 1914 r.

Nic jeszcze $z$ tego, co tu zamierzałam zrobić, nie zrobiłam - leniuchuję jak nigdy, ale za to niewypowiedzianych sensacji dostarcza mi Benedetto Croce ${ }^{6}$. Między innymi jest tam ustęp, który aż prosi się, by, z zacytowaniem go, napisać artykuł o Kostku Biernackim ${ }^{7}$. Ustęp dotyczy generała Bava-Beccaris ${ }^{8}$, komendanta placu w Mediolanie, który uśmierzał rozruchy robotnicze i zmasakrował 450 osób szarżą wojskowa. Benedetto Croce pisze, jak reakcjoniści honorowali go za to: otrzymał podziękowania, wysokie ordery, namówiono nawet Humberta I, aby napisał do niego osobiście.

„Ainsi - powiada Croce - oubliait-on l'antique maxime dont la sévérité excluait tout honneur pour les vainqueurs des luttes civiles" 9 .

Zemściło to się srodze, bo anarchiści właśnie za ten list do Bava-Beccarisa zabili szlachetnego skądinąd Humberta $\mathrm{I}^{10}$. Ale co za nazwisko B a v a - B e c c a ri s!

Wczoraj po dwu dniach odwilży spadł śnieg, a dziś wziął mały mróz. Jutro więc wybiorę się nieco dalej, w lasy i góry.

Podziękuj ode mnie specjalnie Kaziowi i Goetlowi za odłożenie wieczoru ${ }^{11}$. „Kulturę" kupiłam, coś tam za dużo o Rosji. Paczkę otrzymałam. Poza tym z nikim nie widuję się i nie rozmawiam, przy stole tylko muszę wysłuchiwać potoków wymowy „Jeffries” ${ }^{2}$, usiłującej wszystkich epatować „inteligencja”, wyżyną duchową, kato- 
licyzmem, synem, patriotyzmem, poglądami politycznymi etc., etc. Poza tym jest para jakaś „nieoficjalna” - cichy major w cywilu i trudna do zniesienia, prostacka Rosjanko-Polka, w rodzaju Sienkiewiczowej z Łucka ${ }^{13}$, tylko jeszcze bardziej tchnie wschodem i w ogóle brutalna i okropna. Dziś przyjechali jacyś dość przyjemni starzy doktorostwo Benzefowie $z$ Sosnowca. Czop ${ }^{14}$ stanowi obecnie sam cały personel zakładu, bo nie ma i pielęgniarki, tak że i jego prawie nie widuję. W sobotę tylko słuchaliśmy razem Chopina w jadalni, a grane były akurat b[ardzo] ładne rzeczy. Czy słuchałeś? Chcę przyjechać w piątek pociagiem, tym co zawsze odjeżdżamy, rano stąd wyjeżdżającym, a przychodzącym do Warszawy o 2-giej z dużymi minutami, coś przed trzecią. Chyba, że pogoda byłaby wyjątkowo piękna, to może zostałabym do niedzieli rano. Zapewne już specjalnie nie będę powiadamiać, bo pewno datę wyjazdu zdecyduję w ostatniej chwili, więc chyba depeszą?

Naturalnie bez pytania i bez gadania powinieneś Władzię w czwartek posłać do „Kobiety [Współczesnej]” z kartką od siebie upoważniającą do obioru honorarium, ale ten list odbierzesz za późno i pewno sam tego nie zrobisz. A jak jest $z$ honorarium z Prasy Polskiej? Czy Władzia otrzymała? Dołączam kartkę na następne, bo pewno też w ten piątek trzeba będzie posłać.

Całuję Cię bardzo,

Twoja Ma.

List bez koperty; rękopis. Muz. Lit., sygn. 2050, t. 2, k. 129-130.

$1 \quad$ Zachował się jedynie list $\mathrm{z}$ numerem 3, datowany: 4 XII 1931.

2 Publikowana tu kartka z 3 XII 1931, o której wspomina Dąbrowska, poprzedzona była dwiema wcześniejszymi, które nie zachowały się.

3 „Wiadomości Literackie” w numerze 49 z 6 XII 1931 (s. 4, Tydzień bibliograficzny) zamieściły notę o ukazaniu się Bogumita $i$ Barbary z dodatkową informacją: „Pierwszy tom dawno oczekiwanego cyklu powieściowego świetnej pisarki. Dalsze części ukażą się w niedługim czasie pt. Wieczne zmartwienie, Miłość, Wiatr w oczy".

4 Mowa o tomie Wiatr w oczy, nad którym Dąbrowska pracowała.

5 J. C o n r a d, Amy Foster. „Wiadomości Literackie” 1931, nr 48. Nowela ta miała swój pierwodruk w piśmie „Illustrated London News” (1901, nr z XII).

6 Dąbrowska ceniła wysoko pisarstwo Crocego; w Dziennikach notowała pod datą 27 XII 1931: „Nasz krytyk traktuje każdą książke jako sposobność do wypowiedzenia swego siebie. Byłoby to objawem normalnym i nawet bardzo cennym, jeżelibyśmy mieli krytyków tej miary, co choćby Benedetto Croce. Ale gdy krytykami są u nas przeważnie nieudani pisarze, ich żądza wypowiedzenia samych siebie przynosi opłakane rezultaty" (Dz. t. 13, s. 135). Opinie Dąbrowskiej w tym liście dotyczą pracy: B. C r o c e, Storia d'Italia dal 1871 al 1915. Bari 1928. Pisarka czytała książkę w przekładzie francuskim: Histoire de l'Italie contemporaine (1871-1915). Przeł. H. Bé d a ri d a. Paris 1929.

7 W niedatowanym wspomnieniu Rok 1916, dołączonym do Dzienników, M. D ą b r ow s k a pisała o Wacławie Kostku-Biernackim (1884-1957), działaczu sanacyjnym, wojewodzie nowogrodzkim i poleskim, pułkowniku Wojska Polskiego, w latach 1932-1939 komendancie twierdzy brzeskiej: „spotkałam tam osławionego później Kostka-Biernackiego. Patrzyłam na niego z przerażeniem, gdyż służył w żandarmerii Pierwszej Brygady, a nadto o nim i o malarzu Zygmuncie Gumowskim mówiono, że byli "żandarmami wieszającymi». Był to młody człowiek o chorobliwie bladej, przystojnej zimnej twarzy i nieprzytomnych jasnych oczach człowieka pijanego. Pamiętam doskonale przykre i niepokojące wrażenie, jakie na mnie ta zagadkowa twarz wywarła” (Dz. t. 1, s. 62).

8 Fiorenzo Bava-Be c c ar is (1831-1924), generał, polityk, uczestnik wojny krymskiej. Używając armat przeciwko demonstrantom w maju 1898 w Mediolanie, dokonał masakry robotników, w której wyniku zginęło ponad 300 osób. Król Włoch Humbert I po tym wydarzeniu odznaczył generała orderem za męstwo. W roku 1898 został deputowanym do włoskiego senatu. Popierał Narodową Partię Faszystowską. 
„Ainsi...” (franc.) - „W ten to sposób zapomniano o antycznej maksymie, która zwycięzców w wojnach domowych odsądzała od czci i wiary" (przeł. A. Trzn a del-Szcze pan ek).

10 Król Humbert I zginął w zamachu 29 VII 1900 w Monzy, zastrzelony przez anarchistę Gaetana Bresciego.

1114 XII 1931 Dąbrowska miała mieć wieczór autorski wspólny z J. Tuwimem i F. Goetlem w Sali Towarzystwa Higienicznego w Warszawie; zapowiedziany został w „Kulturze” (nr 2). Na prośbę pisarki spotkanie przełożono na 18 XII. Dąbrowska odnotowała w Dziennikach wystąpienie na zebraniu PEN-Clubu, gdzie przedstawiła ostatni rozdział Bogumiła i Barbary. Swoje wiersze prezentował Tuwim, Goetel zaś fragmenty Podróży do Indii.

12 Jeffries - tak ( $\mathrm{z}$ powodu podobieństwa w sposobie bycia do Magdaleny Jeffries) Dąbrowska i Stempowski nazywali Zofię Pe te r s ow ą (1899-1955), literatkę i tłumaczkę, znaną im z kręgu współpracowników Stefanii Sempołowskiej. „Dziś Ty mnie trochę współczuj, gdyż dostałam się w szpony wampirzycy. Nelly Strugowa jest wobec pani Petersowej oazą ciszy. Jestem zagadana na śmierć i przez cztery dni będę we władzy złych mocy" - pisała M. Dąbrowska do Anny Kowalskiej z wyjazdu do Łodzi (karta pocztowa z 7 II 1949. Muz. Lit., sygn. 2153, t. 9, k. 122).

13 Si en ki ewi c zowi e - małżeństwo z Łucka, kuracjusze, których Dąbrowska i Stempowski spotykali w Jaworzu.

14 Jerzy Czop (ok. 1899 - 1939), właściciel i kierownik zakładu leczniczego w Jaworzu, syn Zygmunta Czopa, lekarza, po którym przejął prowadzenie ośrodka. Dąbrowska poznała go jesienią 1927, gdy po raz pierwszy przyjechała do Jaworza. W roku 1929 połączył ich kilkuletni romans. Cechy Czopa noszą w Nocach i dniach Janusz Ostrzeński i Tadeusz Krępski.

\section{Stanisław Stempowski}

[Warszawa,] 2 III [19]32

Kochana Maluśka,

Uzbierała się mała kroniczka, więc spisuję po porządku.

List Ujejskiego skopiowałem, żeby oryginał nie zaginął, i przesyłam. Pochwały jego są ważne, bo odmierzone $z$ wielkim namysłem, a także ze względu na jego udział w jury nagrodowym ${ }^{1}$. Zabawne tylko to „za mało chłopów”, tak samo jak zabawna bywała Twoja trwoga, że „za mało przecinków”. Znać profesora, który gdy powie sobie, że dany utwór należy do szufladki $z$ „klimatem historycznym”, to musi zawierać jak w recepcie: tyle a tyle (w gramach, deci, centi i miligr.) takich a takich elementów społecznych. W ogóle dokoła mówi się tylko o Twojej powieści - nasycona jest nią atmosfera zainteresowań ludzkich. Przypomina to czasy najczarniejszej reakcji politycznej, kiedy utwory naszych pisarzy wielkich wyrównywały krzywdy odsuniętych od działalności publicznej.

Byłem wczoraj u Mortkowiczów. T[om] I już jest w 2-m wydaniu, a II-gi na wyczerpaniu. Liczy, że na wiosnę wydasz jeszcze III-ci tom, żeby nie przerywać impetu. Prawie że mówiły ${ }^{2}$, że książka Twoja ratuje ich sytuację ${ }^{3}$. We wczorajszym „Kur[ierze] Porannym” był o Tobie artlykuł] Leona Rygiera, z przytoczeniem jego listu do Ciebie i Twojej odpowiedzi ${ }^{4}$. Kupię to dziś w redakcji i poślę Tobie. Wczoraj już w kioskach zabrakło. - Telefonowała wieczorem Irena Krzywicka, z która ucięliśmy dłuższą rozmowę. Ma Ci do napisania o entuzjazmie, jaki panuje z powodu Twej powieści w jej środowisku, a więc stary Krzywicki jest zachwycony (będę w niedzielę u niego i sprawdzę), Boy również, a ona II-m tomem też. Dałem jej Twój adres, o co prosiła, więc sama Ci napisze ${ }^{5}$. - W tej chwili wpadła tu (piszę w biurze) Halina Wierzyńska i opowiedziała, jak beczała nad Piotrusiem i Teresa, a przed ciotką zataiła śmierć babci, bo czytała głośno. Rano przychodzi, a ciocia siedzi 
jakaś osowiała w łóżku. Okazało się, że w nocy wykradła książkę i sama odczytała rozdział ze śmiercią babci. „Powiedz mi, moja kochana, czy ta Dąbrowska była kiedy stara, że tak dokładnie wie, co stara kobieta czuje?” A Wierzyńska twierdzi, że posiałaś nieporozumienie w stadłach małżeńskich, gdyż każda żona ma pretensje do męża, że nie jest Bogumiłem. A mężowie nie są wcale pokrzywdzeni, bo w każdej żonie mają jeśli nie całą, to bodaj ułamek Barbary.

Przeglądałem tu „ABC” i znalazłem art[ykuł] endeckiego krytyka Piaseckiego pt. Walki o nagrodę $e^{6}$. Wydziwia krytykom, że wcale nie znają współcz[esnej] literatury polskiej i nie czytają autorów, o których piszą. Więc p. Grubiński kandydata do nagrody widzi we Wroczyńskim za poemat Podniebie ${ }^{7}$. A inni innych. A przecież, prócz Boya, o którym tyle krzyku: Boy i Ojczyzna! - sa jeszcze tacy jak Wołoszynowski z rokiem $1863^{8}$, Dąbrowska z Bogumiłem i A nna. I tu się sam złapał, bo nawet tytułu dokładnie nie przeczytał. Zaiste, żałosny światek.

Na zakończenie bomba: Boguszewski ${ }^{9}$ wygłosił nagle, bez powodu, b[ardzo] ostrą mowę przeciwko reżymowi, której mu nie dano dokończyć. Wycinek załączam.

W domu wszystko w porządku. Była siostra Władzi - jako klientka poradni na Lesznie. Ale nic jej tam nie pomogli, bo mając półroczne dziecko przy piersi zaszła już w ciążę. Cóż to za straszna nędza. Jest chora, wygląda jak cień. Są to skutki przesądu ludowego, że karmiąca kobieta może używać, gdyż jest zabezpieczona. I tu źródło tych niesłychanie krótkich pauz w rodzeniu, które niszczą organizm „nieustannych matek”.

Słyszałem Twój głos, raźny i mężny, w słuchawce telefonu. Stąd wnoszę, że figurka kochana jeździ sobie rankami zdrowo po lodzie przez siebie zamiecionym, a potem - saganek toczy się pomyślnie ku zwycięskiemu zakończeniu. Miłość wymaga takiego raźnego nastawienia autora.

Całuję Twoje ręce.

St.

[Odpis listu Józefa Ujejskiego do M. Dąbrowskiej:]

Warszawa, 27 II 1932

Szanowna i droga Pani!

Jestem już prawie pewny, że Noce i dnie osiagną ten poziom, na który wstępowałem myślami na spotkanie dużej powieści Marii Dąbrowskiej od chwili, gdy się dowiedziałem, że ją pisze. Po drugim tomie widzę już, czego w pierwszym wyraźnie jeszcze nie widziałem: zarysowujący się pewien świat w pewnym duchowym (historycznym) „klimacie”. A poza tym to wieczne zmartwienie jakież i w iluż kobietach prawdziwe - już niezależnie od czasu i przestrzeni. I uwiecznione literacko w tej wiekuistej prawdzie swojej po raz pierwszy! Barbara to iście flaubertowska kreacja - choć tak nic a nic do pani Bovary niepodobna.

Bogumił zszedł teraz troszkę w cień, ale się nie zmienił - jest ten sam co w I-ym tomie, zgodny z sobą w każdym momencie, w każdej reakcji. Cokolwiek przeszarżowany wydaje mi się Daniel. Zresztą wszyscy - dorośli i dzieci, państwo i służba, Żyd i Żydówka (za mało widać chłopów jak na wieś) żyją i cieszą tym, że żyją tak 
naprawdę. Jedyna przykrość, jaką się odczuwa zamykając książkę, to że nie można zaraz otworzyć tomu trzeciego. Serdecznie całuję ręce Pani

\author{
Józef Ujejski ${ }^{10}$
}

List bez koperty; rękopis. Muz. Lit., sygn. 2071, t. 3, k. 5-8.

1 Mowa o jury Państwowej Nagrody Literackiej za 1933 rok, wręczonej Dąbrowskiej w styczniu 1934 za Noce i dnie, jeszcze przed ukazaniem się drukiem ostatniego tomu powieści. W jury, poza Józefem Ujejskim, zasiadali także Juliusz Kaden-Bandrowski, Władysław Zawistowski, Michał Rusinek, Wacław Sieroszewski.

2 Jakub Mortkowicz już nie żył, Stempowski ma tu na myśli jego żonę Janinę i córkę Hannę.

3 Zob. W. Grzelak, Rękopis i metal. „Kultura” 1971, nr 20, s. 5: „Zastrzyk uzdrawiający Wydawnictwo w sumie ogólnej wyniósł co najmniej 200 000, tym bardziej że sprzedawano książkę także bezpośrednio, bez rabatu księgarskiego i sprzedawano komplety w oprawie płóciennej i w cenie skalkulowanej z godziwym zyskiem. A więc 20 proc. olbrzymich długów Wydawnictwa, długów, które spowodowały śmierć Mortkowicza, pokryły Noce i dnie".

4 Leon Paweł Rygi e r (1875-1948), poeta, powieściopisarz, publicysta, pedagog, autor podręczników do języka polskiego, w latach 1907-1909 mąż Zofii Nałkowskiej. W Gabinecie Rękopisów BUW zachowało się pięć listów publicysty do Dąbrowskiej z lat 1931-1936. W recenzji zatytułowanej Noce i dnie (,Kurier Poranny” 1932, nr 61, s. 3) Rygier przytoczył tylko jedno zdanie z jej listu: „Ja rzeczywiście pragnę godzić was i nas przez miłość życia”.

5 Po ukazaniu się tomu 1 Nocy $i$ dni I. Krzywicka pisała do Dąbrowskiej: „Wszyscy czekamy z niecierpliwością na dalsze tomy. Wie droga Pani dobrze, jak żywy i serdeczny był zawsze mój stosunek do Pani, toteż z wielką satysfakcją dołączam swój skromny głos do ogólnego chóru i oczekuję od Pani mnóstwa pięknych rzeczy. [...] Co za styl! To rozumiem!" (list z 18 I 1932. BUW, rkps 1385, k. 273).

6 S. Pi a s e c ki, Huczek koło nagrody. „ABC” 1932, nr 61, s. 4.

7 Mowa o zbiorze K. W r o c zy ń s ki e go Podparnasie polskie (Warszawa 1930).

8 J. Wołoszynowski, Rok 1863. Poznań 1931.

9 Stefan Boguszewski (1877-1938), działacz społeczny i polityczny, senator II i III kadencji Sejmu II Rzeczpospolitej. Podczas swoich przemówień na forum Senatu protestował przeciwko faszyzacji kraju i znęcaniu się nad więźniami politycznymi (ogłosił w tej sprawie list otwarty). W roku 1932 zerwał z BBWR.

10 List J. Ujejskiego z 27 II 1932. BUW, rkps 1385, t. 11, k. 65. Odpowiedź na jeden z listów Ujejskiego przytoczyła Dąbrowska w Dziennikach pod datą 5 I 1932: „Chociaż rozumiem, że stosunek do dzieła sztuki waha się wiecznie między upodobaniem estetycznym a poszukiwaniem "idei przewodnich" - nie mogę się powstrzymać od przypuszczenia, że właściwy stosunek do sztuki nie może się zamykać ani w jednym, ani w drugim z tych stanowisk i leży zapewne w nieco innej płaszczyźnie. [...] Co do mnie, to wyznaję, że dostatecznie ważnym dla mnie problemem wydaje mi się sam fakt życia człowieka i jego zetknięcie się z grozą, dziwnością, zawiłością, tajemnicą istnienia. Jeżeli sprostałam w jakim takim stopniu zadaniu wiarygodnego przedstawienia takiego życia na pewnym realnym odcinku rzeczywistości, to z tego muszą wynikać mnogie zagadnienia społeczne, moralne, filozoficzne, które jednak nie ja będę w bezpośredni intelektualny sposób stawiać i rozstrzygać. To należy do czytelników, do krytyków, uczonych itp. My pisarze dajemy po temu materiał, świat stworzony na nowo $z$ elementów surowej rzeczywistości, zestawiony artystycznie z pełnym miłości pragnieniem, by pomóc nieco życiu, dopełnić je, spotężnić w tych miejscach, gdzie ono jakby spudłowało, nie dociagnęło wątku do końca, zamazało swoje właściwe oblicze. Starałam się oddalić od siebie pokusę, aby przeprowadzić w Nocach $i$ dniach jakąs tendencję czy intelektualną ideę przewodnią, czy dojść w tym utworze do wniosków i konkluzji, gdyż to nie jest rzeczą artysty. Jestem natomiast głęboko przekonana, że jeśli ja sama posiadam jakiś charakter, jakąś moralną czy społeczną wytyczną życia, jakąs postawę wobec świata, to to wszystko znajdzie swoje artystyczne odzwierciedlenie w mojej pracy. A ożywienie, jakie mieli szczęście wzbudzić Bogumit i Barbara, daje mi nieśmiałą nadzieję, że moje powołanie do życia tych postaci nie było tak całkiem nieusprawiedliwione pod tym względem" (Dz. t. 2, s. 141-142). 


\section{Maria Dąbrowska}

$11^{1}$

[Jaworze,] 5 V [19]32

Stachunieczku, najmilszy mój, drogi,

Dziś ma do Ciebie telefonować p. Jasiński ${ }^{2}$ i powie $\mathrm{Ci}$, że chcę przyjechać w niedzielę. Czy jednak nie byłoby rozsądniej dla Barbary, a także by uzyskać zniżkę kolejową, zatrzymać się jeszcze parę dni. Ja Ci powiem, mnie do domu pędzi tęsknota do Ciebie, i to nie wyrozumowana, ale taka czysto emocjonalna, która mnie napada co dzień i częściej, żeby Cię choć zobaczyć, choć pięć minut z Tobą pomówić. Ale obiektywnie biorąc, jest tak: przez dwa pierwsze dni czułam się duchowo bardzo źle, tak że wprost chciałam zaraz jechać, ale potem przełamało się i teraz zdaje mi się, że się z każdym dniem czuję lepiej, po tych dniach zaczęłam pisać, napisałam ładny, b[ardzo] smutny rozdział - wspomnienie Barbary o Toliboskim. Jeżeli udałoby mi się uporać $z$ jeszcze jednym epizodem, to byłoby dobrze. Więc czy nie dobrze byłoby puścić kantem Komisję ${ }^{3}$ ? Ja wnioski mogę bez recenzji napisać i stąd wysłać, jako prowizoryczne, do ewentualnego poprawienia na następnym zebraniu. I może zostanę choć do 11-go? Ale byłabym spokojniejsza, gdybym miała wiadomości od Ciebie. Jedna karta to trochę za mało. Czy aby tylko zdrów jesteś, proszę o telefon albo o parę słów. Jeżeli nie zapłaciłeś mieszkania, to nie płać, ja zapłacę po powrocie, a natomiast prześlij 60 zł Burskiej ${ }^{4} \mathrm{z}$ kartką, którą dołączam. Na balkonie w stołowym pokoju nic nie sadźcie, jak wrócę, będzie jeszcze aż nadto dość czasu. Ja tu prowadze tym razem zupełnie inny tryb życia niż dotąd. Pierwszego dnia zeszłam do stołu, ale to mnie tak denerwowało i zabiera tyle czasu, że teraz już jadam $\mathrm{u}$ siebie, nawet nie na stole, a na kanapce, tak że cały obiad $\mathrm{z}$ wypoczynkiem trwa pół godziny. Nikogo też nie widuję, na pożegnanie tylko z p. Edwardem pochodziłam po ogrodzie. Czop wpada na chwile przed zaczęciem obiadu lub kolacji, ale zaraz go odwołują na dół, zdąży tylko powiedzieć parę słów o jakimś wekslu albo że się czuje zupełnie inaczej, odkąd ja jestem w Jaworzu. Czasem nie wpada, a raczej przyczłapuje się doktorowa, żeby zapytać, czy nie zjadłabym jajeczka, a może szyneczki? Zimińska ${ }^{5}$ jest zupełnie szalona kobieta, a raczej szalonym łobuzem w stylu raczej naszej Wierzejskiej ${ }^{6}$. Mnie ukochała czegoś, całuje mnie po rękach, po nogach, mówi łobuzerskim żargonem. Któregoś wieczora zaprowadziła nas wszystkich do wędrownego cyrku, który rozbił namioty przed apteką. Było to widowisko zupełnie jak u rybałtów z XIII wieku. Opowiem Ci za widzeniem. Obiecałam, że wezmę ją na spacer w góry. Jest ona, zdaje się, bardzo poczciwa. Jest tu również niezwykła postać, stary ksiądz prałat ormiańskiego obrządku, tak wspaniałej gęby z wczesnego flamandzkiego renesansu czy późnego średniowiecza jeszcze nie widziałam. Ma 75 lat i jest głęboko nieszczęśliwy z powodu goniącej za nim przez całe życie miłości kobiet i niemożności pogodzenia tego ze swym zawodem. Ale nie powtarzaj tego, bo to mi Cz[op] mówił w tajemnicy. Tu w ogrodzie szalone zmiany - panie Zimińska i Krzyżanowska ${ }^{7}$ zebrały śród kuracjuszy ogromna składkę i porobiły kwietniki, nasadziły mnóstwo krzewów, drzewek itp. Więc, Stachu, o ile nie będzie mnie w domu w niedzielę najpóźniej do 2.30, to znaczy, że zatrzymałam się do środy lub czwartku. Ściskam,

Twoja M. 


\section{Wszyscy tu po sto razy o Ciebie rozpytują! Kiedy przyjedziesz.}

Ale nie wykluczam, że wrócę w niedzielę.

List z kopertą; rękopis; na kopercie adres: „WPan Stanisław Stempowski, Warszawa, ul. Polna 40 m. 31”. Stempel pocztowy: „Jaworze [data nieczytelna]; Warszawa 1. - 6.V.32-8. "Przegląd Zdrowej Produkcji, 1-8 maja 1932. Targi - Poznań»". Muz. Lit., sygn. 2050, t. 3, k. 14; koperta: k. 15.

1 Numer dopisany ręką Stempowskiego. Zachowały się jedynie cztery listy Dąbrowskiej z Jaworza, wysłane przed 5 V 1932; pierwszy, datowany 4 XII 1931, nosił numer 3 (dopisany ręką Stempowskiego); można przypuszczać, że inne przesyłki to karty pocztowe, które zaginęły.

2 Edward J a sińs ki, rejent z Garwolina, admirator twórczości Dąbrowskiej, wspomagał ją finansowo od r. 1930, zwłaszcza po wybuchu wojny. W czasie okupacji mieszkał w Świdrze pod Warszawą, gdzie leczył płuca i gdzie zapewne zmarł na początku 1944 roku.

3 Mowa o Komisji Oceny Książek do Czytania dla Młodzieży Szkolnej przy Ministerstwie Wyznań Religijnych i Oświecenia Publicznego, której członkiem była pisarka.

4 Burska, krawcowa.

5 Mira Zi mińska - Sy gi e tyń ska (1901-1997), aktorka i reżyserka, którą Dąbrowska znała od 1928 r. i dzięki której otrzymywała bilety do teatru Ateneum. Obie panie bywały u siebie, zwłaszcza w czasie okupacji.

6 Chodzi o Halinę Wierzejska z Puhaczewskich (1894-1975), która w latach 1922-1928 pracowała w Ministerstwie Rolnictwa i Reform Rolnych. Dąbrowska i Stempowski utrzymywali kontakty towarzyskie z koleżankami z pracy; Wierzejskich wizytowali w Brwinowie, od r. 1939 w Zalesiu, gdzie rodzina zamieszkała, gdy Halina wygrała na loterii 4 tys. zł. W Dziennikach pod datą 28 V 1928 Dąbrowska notowała: „Rano jeździliśmy do Brwinowa, do państwa Wierzejskich. (Ona, Halina Puhaczewska $z$ domu, najweselsza i najdowcipniejsza $z$ urzędniczek M[inister]stwa Reform Rolnych, była latami doskonałą sekretarką osobistą ministrów, urzędowała $z$ niewyczerpanym humorem w stylu Zuli Pogorzelskiej - wszyscyśmy za nią przepadali)” (Dz. t. 2, s. 79).

7 Michalina Krzyżan owska, z domu Pi otruszews ka (1883-1962), malarka, żona Konrada Krzyżanowskiego, zaprzyjaźniona z Henrykiem Józewskim i jego siostrą Idalią Korsak, znajoma Stempowskiego i M. Dąbrowskiej. W czasie drugiej wojny światowej włączyła się w działalność konspiracyjną. Po zakończeniu wojny pomagała Józewskiemu, gdy ukrywał się przed Urzędem Bezpieczeństwa aż do r. 1953, gdy to oboje, a także siostra Józewskiego, zostali aresztowani; Krzyżanowską skazano na 5 lat więzienia. Zwolniona w 1955 r. na przerwę zdrowotną w odbywaniu kary, po zmianach politycznych 1956 r. do więzienia już nie powróciła i została w r. 1957 zrehabilitowana. Dąbrowska przyczyniła się, poprzez interwencję u Józefa Cyrankiewicza, do odzyskania przez Krzyżanowską pracowni przy Koszykowej.

\section{Stanisław Stempowski}

$\mathrm{N} 10^{1}$

Jaworze, 13 VII [19]34

Przed chwilą, skończywszy korektę ${ }^{2}$, zawołałem głośno, bo już inaczej nie mogę: - Popuhaj - da poopuhaj - da pooopuhaj!

A chodzi o to, że na początku rozdziału XIV* są dla mnie, jak i każdego innego czytelnika, pewne niejasności: otóż Wikta Kolańszczanka jest jedyną córką mał e g o Tomasza Kolańskiego. Dlaczego „małego”. Ten epitet, użyty jest po raz pierwszy i nic mi nie mówi, a wywołuje pewne zdziwienie, bo i znaczenie ma ambiwalentne, jakby powiedział Jurek. Następnie jest takie zdanie: „Fortuna Kolańskich liczyła się na Starym Serbinowie druga po sołtysach”. Nic nie rozumiem. To jakiś skrót wiadomy tylko Tobie. Co za przeciwstawienie Starego Serbinowa - sołtysom. I skąd fortuna składała się z fortuny sołtysów, skoro w następnych zdaniach jest 
mowa o tym, że synowi sołtysa, Wojciechowi Witczakowi, Kolańscy nie dali córki. A widać to ubocznie $z$ nie dość jasnego wykładu o tym, że „Sołtysiak bowiem rzecz jest inna, skoro jednak nie brała Sołtysiaka itd." Słowem, cała ta historia wydała mi się mętnie i jakoś zawile wyłożona, a takie rzeczy powinien czytelnik połykać skwapliwie i przyswajać w lot, nie rozmyślajace, gdyż wnet rodzi to wątpliwość. Sprawdź to, kochanie, i może co poradzisz, a na mnie nie gniewaj się, żem taki niepojętny i może niepamiętliwy.

Nadeszła w tej chwili (9 rano) i dalsza korekta z ową 63 szpaltą. Zrobiłem ja i odsyłam obie w jednej opasce do Grzelaka ${ }^{3}$. Szybkość rekordowa.

Przyszła mi refleksja: dlaczego $z$ takimi ludźmi, prawdziwymi ozdobami ludzkości, jak ks. Komodziński ${ }^{4}$ i ów hrabia zabity w pociągu - załatwiasz się tak prędko, usuwając ich z życia i powieści absolutnie? I nie tylko Ty, ale wszyscy pisarze. Jaki świat byłby piękny, a życie dobre, gdyby je właśnie takimi zaludnić. Tak, świat byłby piękny, ale powieści pięknej by nie było.

Młodzieńcza „zadziorność” Agnieszki w dyspucie z księdzem i jej obrona masonerii prawdziwe i wzruszające, ale Ty za nią cięgi dostaniesz, mężna niewiasto. Trochę ta cytata $\mathrm{z}$ Apokalipsy w ustach Agnisi nierealistyczna ${ }^{5}$, ale w Braciach Karamazowych Dostojewski wali cała księge o świętości (Cmapeu Зocuna lu ero гоcmu]) złożoną $\mathrm{z}$ cytat ewangelicznych - prawda, że ją wszyscy przy czytaniu powieści przepuszczają i zapamiętują tylko drastyczną scenę, kiedy trup świętego zaczyna śmierdzieć (Тлетворный $\partial y x)^{6}$.

Dziś w nocy obudził mnie szum takiej ulewy, jakiej dawno, chyba jeszcze w dzieciństwie, nie oglądałem. A ranek piękny i może nawet pójdę na kąpiel powietrzną. Do Jadzi posłałem wczoraj, że jeżeli jej tam źle, to niech mi napisze, a pokój dla niej zamówię. Ale czy w „Marysi”7? A dla Ciebie gdzie? „Marysia” górna wolna w tej chwili. Apteka za to pusta ${ }^{8}$.

Czekam odpowiedzi z Ministerstwa ${ }^{9}$, jeżeli nie nadejdzie, w poniedziałek wracam. Jeżeli nadejdzie - czekam Twojego przyjazdu na 20 bm.

Całuję Ciebie.

St.

* szpalta 67.

List bez koperty; rękopis. Muz. Lit., sygn. 2071, t. 3, k. 55-56.

1 Dąbrowska liczyła listy wysyłane z Jaworza od 21 VI 1934 (nie wszystkie numerowała). Stempowski numerował listy Dąbrowskiej z 1934 r. numeracją ciąłą, poczynając od stycznia, jednak często mylił się, np. listowi Dąbrowskiej z 17 VII 1934, ostatniemu przed jej przyjazdem do Jaworza, gdzie mieli się spotkać, nadał numer 56, ale kartka znacznie późniejsza, z Banja Luki, z 9 XI 1934, otrzymała ręką Stempowskiego numer 30. Dąbrowska natomiast wprowadzała kolejne ciagi numerowania dla każdego rozstania osobno, lecz niekonsekwentnie, często zapominając dać numer, a także popełniając omyłki. Był to więc porządek iluzoryczny, a nawet mylący.

2 W czasie pobytu w Jaworzu Stempowski robił korektę części 1 tomu 4 Nocy i dni zatytułowanego Wiatr $w$ oczy.

3 Władysław Grzelak (1896-1977), redaktor, drukarz, kierownik drukarni oficyny Jakuba Mortkowicza. Uważał się za uprzywilejowanego czytelnika Nocy i dni (czytał powieść w trakcie jej drukowania), otrzymał też od autorki pierwszy jej egzemplarz.

4 Pierwowzorem księdza Komodzińskiego w Nocach i dniach był ksiądz Józef Sza fn i c ki (1855-1919), proboszcz parafii w Kokaninie, następnie ks. kanonik w Kościele św. Gotarda w Kaliszu, człowiek, po którym „w Kaliszu nawet Żydzi płakali” - jak pisała J. W a d ow s k a (Nauczyciele średnich 
szkół. W zb.: Pamiętnik Zjazdu Wychowańców Szkół Kaliskich. Kalisz 1923, s. 66). I dalej: „Ks. Szafnicki $z$ taktem i dobrocią odnosił się do wychowanków przeżywających światopoglądowe burze. Bronił ich też przed surowymi represjami władzy szkolnej, a w podniosłych kazaniach wpajał zasady moralne dobra i miłości. Przy całym maksymalizmie etycznym posiadał poczucie humoru, co również przysparzało mu popularności wśród młodzieży” (ibidem, s. 82).

5 Uwaga Stempowskiego dotyczy sporu Agnieszki Niechcicówny z księdzem Komodzińskim, w którym bohaterka odwołała się do Apokalipsy św. Jana 21, 22 (Noce i dnie, t. 3: Miłośc).

$6 \quad$ F. D o st oj ew s ki, Bracia Karamazow (Księga Szósta: Rosyjski mnich. I. Starzec Zosima i jego goście; Księga Siódma: Alosza. I. Powalajacy zaduch).

7 Dąbrowska i Stempowski zatrzymywali się zwykle w gmachu głównym Zakładu; w tym wypadku chodziło o to, by Jadwiga Szumska mieszkała w innym pawilonie lub nawet poza terenem sanatorium. Zapewne w budynku, w którym mieściła się apteka, także wynajmowano pokoje kuracjuszom.

Stempowski zwracał się do Ministerstwa Reform Rolnych, gdzie pracował jako bibliotekarz, z prośbą o zgodę na przedłużenie urlopu.

\section{Maria Dąbrowska}

16

$82^{1}$

Dubrownik, 27 X [19]34

Ach, Stachuniu, jakże tu jest przepięknie! Nie przypuszczałam, żeby po Włoszech coś mogło zrobić na mnie takie wrażenie! Tymczasem Włochy zbladły mi pod czarem Dubrownika. Może i pogoda nadzwyczajna przyczynia się do tego, ale piękność tego krajobrazu jest tak błoga, radosna i [za]razem ekstatyczna, wprost nieziemska, jakby miasto i całe wybrzeże było hymnem, chórem aniołów na chwałę Boga przedwiecznego. Dziś po południu zrobiłam wielki, półtoragodzinny spacer szosą idącą wysoko nad morzem w stronę Kotoru i Cetynii. Morze było tak gładkie i tak ciche jak niebo i przytykało do skalnych występów, okrytych śliczną zielenia, jak szczelnie przylegajaca tafla, bez najmniejszej nawet kryzeczki pian. Po skałach śród laurów, oliwek i cyprysów, które są najpiękniejszymi drzewami świata, świegotało perliście mnóstwo ptaszków, coś w rodzaju śpiewu kanarków. Świegotały nawet ponad morzem. Wyspa Lacroma leży na morzu podobna w zarysie do przedpotopowego jaszczura, $z$ grzbietem wygiętym i na kształt grzebienia tych jaszczurów okrytym sterczącymi rzędem wierzchołkami drzew. Miasto wrasta swymi patetycznymi murami w morze i rozsypuje się ku górze jak stos barwnych kamieni przetkanych zielenią. Słońce zachodziło śród nieba czystego jak łza, ale widać w niedostrzegalną siwą chmurę, bo raptem przybrało najdoskonalszy kształt fezu tureckiego $^{2}$, a w końcu zarysowało się cienkim łukiem przewężonym w środku, niby lecący nad morzem czerwony ptak. Po zachodzie niebo tak dalece zjednoczyło się z morzem, że Dubrownik i wybrzeże zdawały się być lądem rozścielonym śród niebios, barwy liliowo-cielisto-różowawej, a na wschodzie ciemniejącej w fiolet. Wkrótce miasto zaczęło się usiewać światełkami, a dzwony kościołów spotęgowały niewymowną cudowną ciszę. Dzwony są tu teraz jedyną muzyką, gdyż wszelka inna zacichła wskutek żałoby. Miasto całe okryte jest kirem, na każdym domu czarna flaga, nawet $z$ okien porozwieszane czarne makaty. Robi to b[ardzo] silne wrażenie. Nawet okna wystaw przewieszone są na wskoś wstęgą z krepy. Wszędzie mnóstwo fotografii pogrzebu - idącej za trumną królowej jak słup czerni i małego króla 
w krepie. Jest w tym wszystkim poezja wzniecająca czysto fizjologiczne wzruszenie, jakiekolwiek są kulisy tej poezji, jak zresztą ma je, często bardzo ponure i zbrodnicze - każda poezja. Nad tytułami wszystkich dzienników widnieją domniemane ostatnie słowa Aleksandra: Čuvajte Jugoslaviju. Przypuszczam oczywiście, że nowa dyktatura $z$ tego wyniknie, a może i nie. Tylko piąte przez dziesiąte mogę wyrozumieć tutejsze dzienniki. Tutaj nie jest tak bardzo inaczej niż we Włoszech, tylko piękniej. Nawet Florencja i Fiesole nie są tak piękne, a Zatoka Neapolitańska oleodruk, w porównaniu z Dubrownikiem. Ale ślady kultury rzymskiej i włoskiej są tu potężne. Miasto zabudowane prześlicznie, każdy kąt malowniczy i stylowy, żadnego ruchu kołowego w starym śródmieściu. Od głównej ulicy wszystkie boczne $\mathrm{z}$ jednej strony idą schodami b[ardzo] stromo $\mathrm{w}$ górę.

Pensjonacik mój coraz bardziej mi się podoba. Właściciele przyjemni, inteligentni ludzie. Ona, urodzona $\mathrm{w}$ tym domu $\mathrm{z}$ rodziców pochodzenia wiedeńskiego, mąż wiedeńczyk - i dotąd mieszkali w Wiedniu, przyjeżdżając tu tylko na lato do jej rodziców. Dopiero dwa lata temu, po śmierci rodziców, przenieśli się tu na dobre. Maja syna, czternastoletniego Ernsti, podobnego do Joja ${ }^{3}$, tylko znacznie brzydszego i znacznie przyjemniejszego, o ślicznym uśmiechu i wesołych oczach. Pełny życia, zgrabny, opalony na brąz chodzi w koszuli i skórzanych tyrolskich majtkach, krótkich do kolan. Ciagle wrzeszczy "mama” i ciagle toczy zabawną wojnę $z$ tą matką, którą, zdaje się, szalenie kocha. Zaś ta matka jest wysoka, zbudowana jak Diana, opalona jak Hinduska, włosy zupełnie siwe, twarz b[ardzo] przyjemna. Pływają oboje jak ryby i nie wyłażą prawie z kostiumu kąpielowego, przy czym chłopak ciagle żąda, żeby matka robiła $\mathrm{z}$ nim „Entdeckungsreise” ko do sąsiednich skał i grot wybrzeża. Ona krzyczy, że już za zimno łazić mokrym po skałach, nie puszcza go samego, on się dąsa, że matka nigdy mu nie dotrzymuje przyrzeczeń, ale to wszystko na wesoło. Poza tym Ernsti przechodzi sam kurs czwartej klasy i zdaje w Wiedniu, $z$ ojcem przerabia grekę i łacinę i o ile się nie kapie, to siedzi na tarasie nad książkami. Pokoi jest tylko kilka. Oprócz mnie troje gości, wszyscy jak ja - pisarze. Jeden to wiedeńczyk z żoną, b[yły] oficer, który przeszedł wojnę austriacko-włoską i jest podobno znanym pisarzem wojennym, nazywa się Weber. Ciagle b[ardzo] zabawnie opowiada, gęba mu się nie zamyka, grubas. Żona przyjemna, uśmiechająca się i milcząca. Drugi to młody, 24-letni, początkujący pisarz niemiecki, emigrant polityczny, zamieszkały w Paryżu. Ten już w ogóle cały dzień chodzi w kostiumie kąpielowym. Ja się tu już n i e k ą p i ę, tylko myję się w morzu i wciagam wodę do nosa. I leżę na skale w słońcu, które już zbyt nie pali, a strasznie przyjemnie grzeje. Kąpiel tu jest możliwa tylko dla dobrze pływających, bo zaraz o dwa kroki od kamienistego brzegu - głębia. Dziś wysłałam ekspres do Günthera ${ }^{5}$ i czekam teraz na odpowiedź.

[Dopisek u góry pierwszej stronicy:] Kartka ze statku była 12, kartka nienumerowana $-15^{6}$.

List z koperta; rękopis; na kopercie adres: „WPan Stanisław Stempowski, ul. Polna 40 m. 31, Warszawa, Polj ska; Expres: Maria Dombrowska, Jugoslavia Dubrownik, Ploče 14". Stempel pocztowy nieczytelny. Notatka ręką Stempowskiego: „15; otrz. 31/X”. Muz. Lit., sygn. 2050, t. 4, k. 48-49; koperta: k. 50 .

1 Numer dopisany ołówkiem ręką Stempowskiego. Być może, wpisując liczbę 16, Dąbrowska pomy- 
liła się w numerowaniu (list powinien mieć numer 11) lub tė̇ - wysłała kartki pocztowe, które nie zachowały się.

2 Tu rysunek wykonany ręką Dąbrowskiej.

3 Jojo - Jerzy S ta v r o, syn Marty Stavro, siostry Jerzego Czopa, stale mieszkający wraz z rodzicami w Wiedniu. W czasie letnich wakacji bywał wraz z matką w Jaworzu, gdzie, wówczas kilkunastoletniego, poznała go Dąbrowska.

4 „Entdeckungsreise” (niem.) - „odkrywcza podróż”.

$5 \quad$ Władysław G ünther-Schwarzburg (1885-1974), dyplomata, wolnomularz, tłumacz z języka francuskiego. Doktoryzował się na wydziale romanistyki UJ, ukończył także Sorbonę. Był posłem nadzwyczajnym i ministrem pełnomocnym RP w Królestwie Jugosławii (1931-1935), następnie posłem przy rządzie greckim w Atenach (w r. 1937 uzyskał także akredytację na obszar Albanii) i na uchodźstwie (1936-1942).

6 Być może, cztery kartki zaginęły lub nie zachowały się, albo Dąbrowska pomyliła się w numeracji.

\section{Maria Dąbrowska}

Ciechocinek, 18 VIII [19]39

Piątek, o 7.30 rano

Zrobiłam tedy wczoraj nie tylko ciekawa wycieczkę, ale jakby wyprawę do moj ego o s o bi s te go Biskupina. Już w Orbisie dowiedziałam się, że droga do Kruszwicy prowadzi przez Radziejów, i aż mi serce podskoczyło $z$ radości i z emocji. Po tylu latach życia na świecie miałam wreszcie pierwszy raz zobaczyć własnymi oczami te strony, skąd wywodzi się nasza matka.

Jechało się przez toż samo Służewo, co do Inowrocławia. Jest to majątek $z$ wielkim parkiem i skrytym w jego głębi dworem czy też pałacem i osadą, z ładnym starożytnym kościołem. Potem - Straszewo, Syroczki, Zakrzewo, Sędzin, Sędzinek i Dobre (cukrownia). Wszystko - wielkie majątki z parkami, piękne stare drewniane kościółki, wspaniałe nowe gmachy szkolne, pyszne gleby, potężne urodzaje, po dwanaście stert na jednym polu stoi. Już pewno od Bolesława Krzywoustego nie dawano się tu osiedzieć chłopom i do dziś w tych najlepszych w rdzennej Polsce glebach nie ujrzysz chłopskich łanów. Natomiast gdzie tylko pojawiają się lżejsze grunty, natychmiast pojawiają się i chłopskie gospodarstwa. Gdyby nic innego nie świadczyło, już to samo świadczy o rugach i przemocy, jaką się ustrój pańszczyźniany, a potem folwarczny kształtował. Jużci, nikt $z$ własnego natchnienia nie pójdzie na gorsze grunty.

Za osadą Chełmce $z$ prawej strony zobaczyłam na horyzoncie Radziejów. Miasteczko rozrzucone jest po zboczach nieznacznego, ale na zupełnej równinie, dość wyniosłego wzgórza i spiętrza się na jego szczycie w stos domów uwieńczony wieżami dwu starych kościołów. Patrząc na ten widok słyszałam słowa matki: „Miasto było, pamiętam, owszem, dosyć ładne, wysoko położone, z naszego mieszkania mieliśmy piękny widok naokoło. Były też, pamiętam jak przez mgłę, piękne stare kościoły". Tu bowiem, gdzieś pomiędzy Radziejowem a Kruszwica, odległa o 8 km, nad samym dawnym kordonem pruskim, były folwarki mego pradziada, Wrąbczyn i Branno, które babka moja dostała w wianie i które dziad mój, Feliks Gałczyński (fotografia portretu nad moim tapczanem) stracił, a zbiedniawszy, tułał się po dzierżawach (Gawrony i Lorenki), a na koniec, jak Huba ${ }^{1}$, został burmistrzem w Radziejowie, gdzie we własnym mieszkaniu w ratuszu znalazł śmierć od pioruna. W tymże też Radziejowie jest pochowany. Gdy przejeżdżaliśmy przez rynek, 
szofer pokazał mi ów ratusz, ani wiedząc, jakie obrazy on we mnie wywołuje. Jest odnowiony, ale podobno ten sam, co był przed osiemdziesięciu laty. Mimo woli widziałam oczami duszy tę burzę, poruszenie całego miasteczka tak osobliwą śmiercią burmistrza, ratowanie starej piastunki Bursztynki, która była też kontuzjowana, tak że zakopywali ją w ziemię, ,żeby wyciągło”, no i przyszła jeszcze do siebie. Potem widziałam karete pocztowa i moją babke $z$ trzema synami wyrostkami i dwoma córkami: siedmioletnią Julcią (matką Stelli) i pięcioletnią Ludką (naszą matką), wyruszającą w podróż aż do Piotrkowa ${ }^{2}$, zapewne przez wielkie lasy, które jeszcze wtedy znaczną część okolic Radziejowa stanowiły. Było to wszystko w r. 1860 lub 61. Na rynku Radziejowa, po którym chodziły stopki dziecinne mojej matki, zauważyłam dwa piękne stare domy dworkowe, murowane, $z$ ładnymi kamiennymi schodami. To przypomniało mi opowieść babci, że na kamiennych schodkach upadła i wybiła sobie przednie zęby. Może to były właśnie jedne $z$ tych schodków?

Matka opowiadała mi, że ze szczytu ratusza oglądała w Radziejowie Gopło i Wieżę „Mysią", które są rzeczywiście tuż, tuż. Tak więc ród mój i ja - wyszliśmy z tego samego zakątka, $\mathrm{z}$ którego wyszła cała Polska.

W Kruszwicy zwiedziliśmy naprzód kolegiatę, zaczętą w XI, skończoną w XII wieku, z których to czasów zachowała się absyda i chrzcielnica, i parę odrzwi kamiennych, wszystko bardzo stylowo romańskie. W kolegiacie też pokazują rzekomy portret Marcina Gallusa, kronikarza Bol[esława] Krzyw[oustego] ${ }^{3}$, ale to fantazja, jak i to, że miał być jakoby biskupem kujawskim.

Najprzyjemniejszą częścią wycieczki była przejażdżka motorówką po Gople. Wbrew temu, co zwykle opowiadają zwiedzający, Gopło jest bardzo ładne i, przy mojej wyobraźni, zrobiło na mnie wrażenie. Jezioro przepływa przez miasto wąsko jak rzeka, tak że nawet przerzucono przez nie dwa mosty, za miastem jednak rozszerza się znacznie, ma w ogóle długości $32 \mathrm{~km}$, a szerokości w najszerszym miejscu 2 i pół km. Może też prześliczna pogoda dodawała uroku wodom srebrno-błękitnym, przejrzystym i spokojnym. Brzegi zarośnięte trzcina gnieżdżą niezmierne mnóstwo ptactwa. Po prostu setkami pływały po całej powierzchni kurki wodne, kaczki i nurki czy też perkozy, śliczne ptaki, z długą szyja, białą kamizelką, czubkiem i pierzastym kołnierzem jak u dalii.

Na Wieżę „Mysią”, która pochodzi co najwyżej z XII wieku, nie wchodziłam, aby nie męczyć serca, bo to chyba $\mathrm{z}$ dziesięć pięter, żałowałam pięknego stamtąd pewno widoku, ale nie miałam odwagi. Wieża jest czworokątna, ceglana, z małymi otworkami na strzelnice, po bokach rozsypujące się szczątki murów, które musiały otaczać cały gród. W murach tkwią kamienne pociski, może to kule oblężnicze Bolesława Krzywoustego, który tu oblegał swego brata Zbigniewa ${ }^{4}$.

Na koniec zwiedziliśmy fabrykę win owocowych Makowskiego ${ }^{5}$. Ten Makowski, całkiem prostoduszny „Poznaniok”, sam oprowadził nas i wszystko pokazywał, i ma widać zmysł propagandy, bo mnie nawet zachęcił do tych win. Kiedy pokazywał nam halę olbrzymich beczek o zawartości 6 do 10 tysięcy litrów, wskazał na stojącą, a raczej leżącą osobno beczkę starożytnej roboty, pięknie rzeźbioną, którą nabył dla jej piękności przy likwidacji zbankrutowanej warszawskiej firmy winnej Zeidla ${ }^{6}$. Nawet więc w takim ukryciu jak piwnica winiarza każdy przedmiot użytkowy dawnych czasów był piękny w porównaniu z dzisiejszymi. 
18/VIII, godz. 12-ta rano

Przerwałam list, bo trzeba było iść na „zawijanie borowinowe”. Po powrocie i przepisanym dwugodzinnym leżeniu, kończę. Nadszedł już Twój list 7-my z listem Zawodzińskiego. Co do Wacków ${ }^{7}$ i co do Zawodzińskiego masz zupełną rację. Ale gdybyś był czytał mój list do Zawodz[ińskiego], nie myślałbyś, że go chcę zrażać, tak był pełny wyrazów szacunku i liczenia się z jego zdaniem.

Co do pójścia $z$ Turem ${ }^{8}$ na Wesele Fonsia, to chyba żartujesz albo udajesz, przypuszczając, że mogłabym mieć o to pretensje. Ładne miałbyś o mnie pojęcie, gdyby ta obawa była serio. Oczywiście strasznie się ucieszyłam, że zrobiłeś mu choć taką błahą przyjemność w chwili, gdy tego potrzebował.

Tutaj był film Trzy serca z Elżunią ${ }^{9}$. Chciałam na to pójść, ale tu każdy film idzie tylko trzy dni i nim się obejrzałam, już go zdjęli.

Do Niszczewic bardzo chcę pojechać, choć aby zajrzeć, czy tam są warunki dla dłuższego pobytu mojego, „względnie” naszego. Grubasiński ${ }^{10}$ nie ma racji, zabraniając mi tych wycieczek, bodźce psychiczne są dla mnie szczególnie lecznicze. Może uda mi się to wykroić w ten sposób. 24-go kończę kurację. Po południu wyjechałabym do Złotnik Kujawskich (podróż koleją trwa $1^{1 / 2}$ godziny, 25-go wróciłabym tu i 25-go wieczorem albo 26-go rano wróciłabym do Warszawy).

Dziś wybieramy się z Mazurkiewiczami ${ }^{11}$ do Raciążka, tu blisko, nad Wisłą, $z$ ruinami zamku, w którym królowa Jadwiga zjeżdżała się z mistrzem krzyżackim Konradem von Jungingen i miała do niego wspaniałą uczoną mowę, aby go odwieść od działań przeciw Polsce i nakłonić do zwrotu Ziemi Dobrzyńskiej. Nie byle jaka to była, jak się okazuje, dyplomatka.

\section{Całuję Cię serdecznie,}

Ma.

A ten winiarz Makowski syci też miody i ma ogromna pasiekę nad Gopłem. Że i Piast sycił pewno miody - takiego to więc mamy dziś następcę Piasta.

List bez koperty; rękopis. Muz. Lit., sygn. 2050, t. 5, k. 61-62.

1 Sformułowanie Dąbrowskiej jest mylące; Hubert Stempowski nie był burmistrzem w Radziejowie, był starostą włodzimierskim i prezydentem Łucka.

2 Dziadek pisarki, Feliks Gałc zyń s ki, w r. 1960 został burmistrzem w Radziejowie na Kujawach; w r. 1861 zginą tragicznie od uderzenia pioruna. Po jego śmierci Józefa Gałczy ńs ka, z domu Maj ew s ka, nie wyszła ponownie za mąż; prowadziła stancję w Piotrkowie i sama wychowywała sześcioro dzieci: synów Bronisława, Józefa i Włodzimierza, oraz córki: Julię, Ludomirę (matkę M. Dąbrowskiej) i Felicję. Wszystkie dzieci Józefy pobierały wykształcenie - chłopcy uczyli się w gimnazjum gubernialnym, dziewczetta na pensji Panien Dominikanek w Piotrkowie. Aby kształcić dzieci na wyższym poziomie, Józefa Gałczyńska przeniosła się do Kalisza.

3 G. Le n g n i c h, wydając w Gdańsku Kronikę polską Galla Anonima, jako jej autora podał Marcina Gallusa, myląc Anonima $z$ Marcinem Galikiem.

$4 \quad$ Z big n i ew, w latach 1102-1107 książę Wielkopolski, Mazowsza i Kujaw, przyrodni brat Bolesława Krzywoustego, z którym rywalizował o władzę zwierzchnią w Księstwie Polskim. Oślepiony, wkrótce potem zmarł.

5 Henryk Makowski (1880-1945), absolwent Akademii Rolniczej w Humaniu, wytwórca win. Założył w Kruszwicy bardzo nowoczesną na owe czasy Kujawską Wytwórnię Win, która szybko stała się największym w kraju producentem win i soków. W roku 1939 przedsiębiorstwo zostało przejęte przez Niemców, w r. 1945 znacjonalizowane. Makowski zmarł w niewyjaśnionych okolicz- 
nościach w areszcie NKWD w Bydgoszczy, zapewne aresztowany w związku z jego aktywnością polityczną w BBWR w okresie międzywojennym.

6 Mowa o firmie winiarskiej Dom Handlowy i Skład Hurtowy Win „Maurycy Seydel i S-ka”, mieszczącej się przy ul. Senatorskiej 36/38 w Warszawie.

7 Chodzi tu o Wacława Dąbrowskiego i jego żonę Wandę, z domu K o c i eł (1884-1974), bibliotekarkę, bibliografkę, działaczkę oświatową, nauczycielkę.

8 Leonard Tur (1888-1939), inżynier agronom, wolnomularz. W latach dwudziestych był naczelnikiem wydziału w Departamencie Administracyjnym Ministerstwa Reform Rolnych, w r. 1927 został naczelnikiem Centrali Wydziału Rolnego Państwowego Banku Rolnego. Był bliskim przyjacielem Stempowskiego i Andrzeja Struga. Zmarł w czasie oblężenia Warszawy w 1939 roku.

$9 \quad$ Trzy serca (film obyczajowy). Reżyseria: M. W a s zyń s ki. Scenariusz według własnej powieści: T. Dołęga - Mos tow i cz. Scenografia: S. Norris. Muzyka: Z. Wi ehler. Produkcja: Wytwórnia Feniks. Premiera: 17 III 1939.

W roli Kasi, wychowanicy hrabiny Tynieckiej, obsadzono Elżbietę Barszczewską. W filmie wystąpili także m.in. Aleksander Żabczyński i Aleksander Zelwerowicz.

10 Przemysław Ru d z k i (1877-1940), lekarz internista, działacz polityczny i społeczny, wolnomularz. Studiował medycynę w Warszawie i Pradze; w Warszawie działał w Czytelni Naukowej, gdzie poznali się ze Stempowskim. Pracował jako lekarz przyfabryczny, następnie był lekarzem i dyrektorem zakładu w Nałęczowie. Działał w PPS, był współzałożycielem Lubelskiego Towarzystwa Szerzenia Oświaty „Światło”. W czasie pierwszej wojny światowej zamieszkał w Warszawie, latem bywał ordynatorem w Ciechocinku, prowadząc jednocześnie kursy dla lekarzy. S. S t e m pow s ki poświęcił mu obszerne wspomnienie w swoich Pamiętnikach 1870-1914 (Wrocław 1953, s. 394-396).

11 Jan Mazurkiewicz (1871-1947), lekarz, profesor psychiatrii i rektor Uniwersytetu Warszawskiego, twórca warszawskiej szkoły psychiatrycznej, prezes Polskiego Towarzystwa Psychiatrycznego, wolnomularz, w latach 1929-1931 Wielki Mistrz Wielkiej Narodowej Loży Polskiej. Jego żoną była Zofia, z domu Za le s ka (1886-1974). Stempowski związany był z Mazurkiewiczem działalnością wolnomularską, Dąbrowska poznała ich dopiero w 1939 roku.

\author{
Abstract \\ MARIA DĄBROWSKA-STANISŁAW STEMPOWSKI FROM LETTERS 1924-1939 \\ Edited by \\ EWA GŁEBICKA Institute of Literary Research of the Polish Academy of Sciences, Warsaw
}

The nineteen letters by Maria Dąbrowska and Stanisław Stempowski selected from the corpus of their correspondence were written in the years 1924-1939. They represent a sort of epistolary writings characteristic of them in which everyday problems are intertwined with reflections on their works, their coverage on literary and cultural events as well as current political and social issues. The whole correspondence by Dabrowska and Stempowski from the years 1924-1951 amounts to a thousand and thirty eight extensive letters which, as in the lens, focus on histories of the Polish intelligentsia, its ambitions as well as their ethos of life and work. 